\title{
Growth and seasonal fluctuations in size and condition of male Northwest Atlantic harp seals Phoca groenlandica: an analysis using sequential growth curves
}

\author{
D. Chabot ${ }^{1, *}$, G. B. Stenson ${ }^{2}$ \\ ${ }^{1}$ Institut Maurice-Lamontagne, Fisheries and Oceans Canada, PO Box 1000, Mont-Joli, Quebec G5H 3Z4, Canada \\ ${ }^{2}$ Science Branch, Fisheries and Oceans Canada, PO Box 5667, St. John's, Newfoundland A1C 5X1, Canada
}

\begin{abstract}
Pinnipeds have marked seasonal changes in body condition, accumulating energy reserves prior to the reproduction period, and depleting these reserves during the breeding and molting periods. This cycle is not well described in male harp seals Phoca groenlandica. We obtained morphometric measurements for 3167 Northwest Atlantic male harp seals sampled between 1979 and 1995. The part of the yearly cycle covered in this study (November to May) was divided into short blocks around median dates called 'periods'. For each period, a growth curve was calculated for body mass, sculp mass, core mass and standard length. These sequential growth curves were used to calculate changes in size-at-age between periods. In addition, seasonal changes in 3 condition indices (general, sculp and core condition), in blubber thickness and in the ratio of sculp to total mass were analyzed using locally weighted regressions. Male harp seals returned from their high-latitude feeding grounds heavier, in better condition, and with a thicker blubber layer than when they left the area in the spring. However, maxima in length, mass, condition and blubber thickness were not observed until the February 22 period (February 12 to March 4), or in the case of seals younger than 5 yr, sometime in March. Mass losses associated with the rut began between the periods February 22 and March 15 (March 5 to 25) and were most pronounced in seals older than 10 yr. About $66 \%$ of the losses in mass came from the core during this period. We estimated that males lost $39.4 \mathrm{~kg}$ during the rut ( $1.16 \mathrm{~kg} \mathrm{~d}^{-1}$ or $0.78 \%$ of initial mass $\mathrm{d}^{-1}, 44 \%$ from sculp and $56 \%$ from core) and incurred energy expenditures of $840 \mathrm{MJ}\left(24.7 \mathrm{MJ} \mathrm{d}^{-1}\right)$. This corresponds to twice the standard metabolic rate (SMR), and suggests that males are feeding during the rut. All males lost mass in April, and again in May. They began to molt April 19 period (April 16 to 22). Fewer than half the seals had completed the shedding of old hair when the study ended, in the May 10 period. Rates of mass loss during the molt varied from 1 to $1.8 \mathrm{~kg} \mathrm{~d}^{-1}$, depending on the age of the seals. Minima of length, mass, condition and blubber thickness were observed in May. Molting appears to be a period of high energy expenditures ( 3 to 5 SMR) despite the low levels of activity observed at this time. This study revealed that length also changes seasonally: fat seals in February were longer than lean seals of the same age in late April.
\end{abstract}

KEY WORDS: Harp seal · Phoca groenlandica $\cdot$ Growth $\cdot$ Condition · Morphometrics $\cdot$ Males

\section{INTRODUCTION}

Most pinnipeds display seasonal cycles of food ingestion and body size or condition. In particular, phocid seals accumulate energy reserves prior to reproduction

*E-mail: chabotd@dfo-mpo.gc.ca
(Sivertsen 1941, Sergeant 1973, 1991, Fedak \& Anderson 1987, Nilssen 1995). Even though seals are well adapted to their aquatic environment, they must haul out on solid substrate, land or ice to give birth and to molt. As a result, their ability to forage during these periods is limited. Some species, such as the northern elephant seal Mirounga angustirostris and southern elephant seal $M$. 
leonina (Costa et al. 1986, Deutsch et al. 1990, Slip et al. 1992, Hindell et al. 1994) and the gray seal Halichoerus grypus (Fedak \& Anderson 1982, Anderson \& Harwood 1985), fast completely and lose mass (although Baker et al. 1995 found evidence of feeding in ice-breeding female gray seals). Other species, such as the harbor seal Phoca vitulina and the harp seal Phoca groenlandica, may ingest some food, but are nevertheless in negative energy balance during the breeding period (Sergeant 1991, Walker \& Bowen 1993, Nilssen 1995).

Mass has a direct impact on the energy requirements of an animal because metabolism changes with body size (Brody 1964, Kleiber 1975, Schmidt-Nielsen 1984). Seasonal changes in mass are a reflection of the ratio of energy ingested to energy requirements. Thus it is essential to know the mass of the individuals in a population, as well as any seasonal fluctuation in mass, to understand the energy requirements of a population of predators and their impact on populations of prey. Ideally, such knowledge should be combined with measures of metabolism, because the metabolism of seals alters according to their nutritional level (Markussen et al. 1992, Boily \& Lavigne 1995, Markussen 1995). There is also some evidence of seasonal changes in their basal metabolic rate, BMR (Renouf \& Gales 1994, Rosen \& Renouf 1995, Boily 1996, Boily \& Lavigne 1997, Hedd et al. 1997).

The harp seal is the most abundant large piscivorous predator in the Northwest Atlantic. Numbering an estimated 4.5 to 4.8 million in 1994, this population could be increasing by $5 \%$ every year (Shelton et al. 1996). Growth, and thus size at age, have been described (Innes et al. 1981, Hammill et al. 1995), but data from different times of the year were pooled, thus introducing seasonal variation as a confounding variable. Knowledge of the seasonal changes in body mass and condition is sketchy, especially for males and for immature individuals. Seasonal cycles in body mass are best studied by taking multiple measurements on known individuals through time. This is most easily done for species that spend extended periods of time on land, or return predictably to the same site several times a year. However, the harp seal has a pelagic lifestyle. Its breeding and molting periods are short, lasting about 1 mo each (Sivertsen 1941, Sergeant 1965, 1973, 1991). Furthermore, they haul out on pack ice, the location of which varies between and within years (Sivertsen 1941, Sergeant 1965, 1973, 1991). Therefore, longitudinal studies on harp seals in their natural habitat are available only for lactating females and for pups in the first few months of their life (Stewart \& Lavigne 1984, Oftedal et al. 1989, Kovacs et al. 1991, Lydersen \& Kovacs 1993, 1996). There have been a few longitudinal studies with captive harp seals (Renouf et al. 1993, Lager et al. 1994), but sample sizes were small, and there were differences in mass, blubber thickness and in the timing of events such as the molt between these seals and wild individuals.

By necessity, the study of seasonal cycles in mass and condition of harp seals relies on cross-sectional data or the measurements of different animals at different times. Sergeant $(1973,1991)$ described seasonal fluctuations in blubber thickness and condition of adult harp seals throughout the yearly cycle, but sample sizes were often small and no data on mass were given. Although indicative of the changes in energy reserves of harp seals, such indices do not allow direct calculation of the energy ingested or expended by seals. Beck et al. (1993) measured mass and body composition of harp seals, but their seasonal coverage was incomplete. Furthermore, with the exception of a few seals from Northern Quebec, their seals were sampled in the Gulf of St Lawrence, even though the bulk of the population overwinters off Newfoundland and Labrador.

We have collected data from a large sample of harp seals collected off Newfoundland and Labrador between November and May 1979 to 1995. In this paper, we describe seasonal cycles in length, body mass, sculp (skin and blubber) mass, core (lean carcass and viscera) mass, blubber thickness, condition and the ratio of sculp to total mass of male harp seals. We provide allometric equations relating total mass, sculp mass and core mass to body length at different times of the year. In a future paper, we shall do the same for females, and investigate possible inter-annual variations in size and condition. To reduce some of the biases often plaguing cross-sectional studies, such as variations in sample size and age distribution of samples from different time periods, we have expanded a technique first proposed by Wood et al. (1962). These authors fitted growth curves to measurements obtained in spring, when black-tailed deer Odocoileus hemionus were lean, and in fall, when they were fat, thus improving the precision of their growth estimates, and gaining a novel way of quantifying seasonal changes. Seasonal changes in body mass of brown bears Ursus arctos have also been studied with growth curves (Kingsley et al. 1983). Here we take this technique one step further, computing growth curves over many short intervals to capture seasonal changes in size and in body composition that are not simple sinusoidal functions of date. An additional advantage of this technique is the ability to describe growth without the confounding effect of seasons.

\section{MATERIALS AND METHODS}

Data collection. Male harp seals Phoca groenlandica were sampled off the coast of Labrador and the north- 
east coast of Newfoundland between 1979 and 1995. A few seals were also collected off the south and west coasts of Newfoundland (Fig. 1). Seals were collected by Department of Fisheries and Oceans researchers, commercial sealers, or as incidental catch in fishing gear. All seals were taken under a commercial or scientific permit and recorded as part of the total removals for the species. The majority of seals were shot and measured in the field, but samples from the Labrador coast (November and December) were caught in gillnets and frozen, being thawed before measurements were taken. Date, time, location, sex and pelage condition (hair loose or fast, determined by pulling on clumps of hair) were noted. Standard length ( $L$, to the nearest $0.5 \mathrm{~cm})$, total mass $\left(M_{\mathrm{t}}\right.$, to the nearest $\mathrm{kg}$ for large individuals, and to the nearest $0.5 \mathrm{~kg}$ for smaller seals), axillary girth $(G$, to the nearest $0.5 \mathrm{~cm})$, and blubber thickness $(B$, to the nearest $0.1 \mathrm{~cm})$ were measured following the recommendations of the American Society of Mammalogists (1967), except that $B$ excluded the skin. $M_{\mathrm{t}}$ was corrected for the mass of the stomach content, but not for blood loss in shot seals. The skin and blubber were removed together and weighed $\left(M_{\mathrm{s}}\right.$ to the nearest $\left.0.5 \mathrm{~kg}\right)$. Changes in sculp mass between time periods are interpreted as changes in blubber (fat) mass, and changes in skin mass are assumed to be negligible. Core mass $\left(M_{\mathrm{c}}\right)$ was calculated as the difference between $M_{\mathrm{t}}$ and $M_{\mathrm{s}}$. Age was determined by counting dentinal annuli from a cross-section of a lower canine tooth (Bowen et al. 1983) and assuming seals were born on March 7 (Myers \& Bowen 1989).

To distinguish between measurement or transcription errors and valid extreme values, we looked for inconsistencies in the ways in which the morphometric variables varied together by calculating linear regressions between selected variables, such as $M_{\mathrm{t}}$ and $L$ (after logarithmic transformation) (Chabot et al. 1996). Cases with a Studentized residual $\geq 3$ SD were verified and corrected if needed, and those with a Studentized residual $\geq 4 \mathrm{SD}(0.3 \%$ of the cases) were considered outliers and excluded from the analyses. We only retained seals collected after Day 316 (corresponding to November 12 on non-leap years) or before Day 140 (May 20), and for which age, $L, M_{\mathrm{t}}, M_{\mathrm{s}}, G$ and $B$ were all measured. Pups and newborns presented problems when fitting growth curves (see below); therefore individuals $\leq 0.5 \mathrm{yr}$ were excluded. Additional data meeting these criteria were obtained for harp seals collected in the Gulf of St Lawrence (Hammill et al. 1995, Innes et al. 1981) (Table 1).

Two methods were used to study seasonal changes. In the first method, length and mass data were combined into short time periods based on sampling date. Growth curves were then computed for $M_{\mathrm{t}}, M_{\mathrm{s}}, M_{\mathrm{c}}$ and

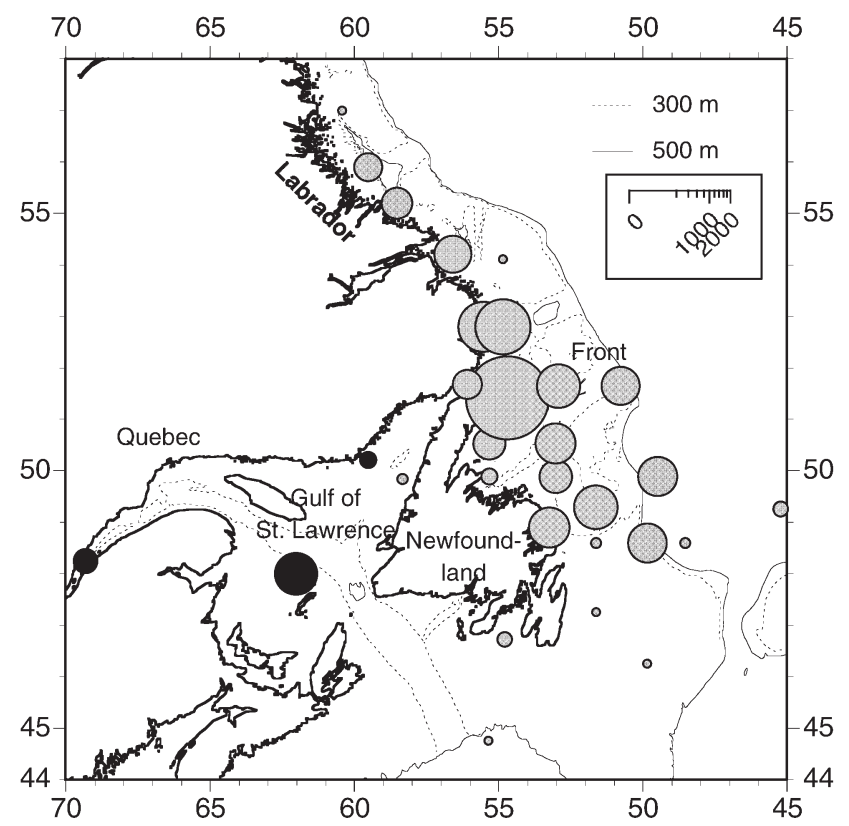

Fig. 1. Phoca groenlandica. Geographic distribution of the males collected over the entire study period (November to May, 1979 to 1995). Grey circles: original data; black circles: data from Innes et al. (1981) and Hammill et al. (1995); size of circles represents sample size, with largest circles indicating greatest numbers. A sample of 23 seals from Innes et al. (1981) is not shown, but came from the Front at the beginning of the molting season, probably from around $51^{\circ} 25^{\prime} \mathrm{N}, 54^{\circ} 40^{\prime} \mathrm{W}$

$L$ for each period. The duration of these periods was generally $3 \mathrm{wk}$, with 2 exceptions. Because mass changed rapidly in April and sample sizes were large, we combined data by week from Day 106 (April 16) to Day 119 (April 29), and because of small sample sizes, seals sampled between Day 358 (December 24) and Day 21 (January 21) (4 wk) were grouped together. The periods are described in Table 1, along with corresponding dates and median date, assuming non-leap years. Thereafter we refer to the periods by their median date. Sample size for each time period and each sample are given in Table 1. In the second method, a general condition index was computed as the ratio (in \%) of $M_{\mathrm{t}}$ to $\hat{M}_{\mathrm{t}}$ (mass predicted from $L$ according to the mass-length relationship derived in this study). Similarly, sculp and core conditions were computed as the ratio of $M_{\mathrm{S}}$ to $\hat{M}_{\mathrm{S}}$, and $M_{\mathrm{C}}$ to $\hat{M}_{\mathrm{C} \text { ' }}$ respectively. The ratio of $M_{\mathrm{s}}$ to $M_{\mathrm{t}}$ was also computed. Condition indices, $B$ and the ratio of $M_{\mathrm{s}}$ to $M_{\mathrm{t}}$ for seals aged $1,3,5,7,10$ and $15+$ yr were then plotted against time, and fitted by locally weighted regressions (Cleveland 1979, Synergy Software 2000), using a weighing factor of $50 \%$.

To calculate the energy equivalent of mass losses, we assumed $5 \%$ water content in harp seal blubber 
Table 1. Phoca groenlandica. Number of male harp seals for each time period, by sample, age class and pelage condition. Dates for each period are indicated for a non-leap year. Age was rounded to the nearest integer, e.g. for the period from November to May, Age $1=0.66$ to 1.2 yr. NF: original data collected off Newfoundland and Labrador; G81: data from Innes et al. (1981); G95: data from Hammill et al. (1995)

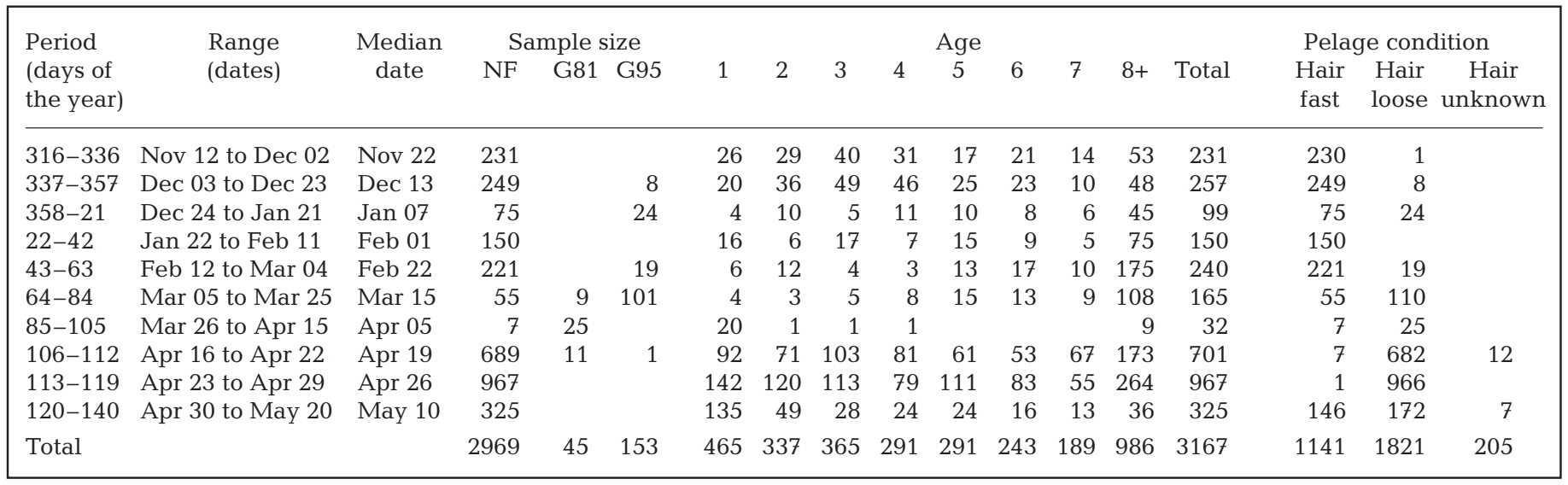

(Beck et al. 1993, Gales et al. 1994), and that only neutral lipids (39.8 $\mathrm{MJ} \mathrm{kg}^{-1}$, Lucas 1993) were used as fuel, as in harp seal pups (Worthy \& Lavigne 1983b). Hence, the energy equivalent of sculp was $37.8 \mathrm{MJ} \mathrm{kg}^{-1}$. The core of harp seals is about $5 \%$ lipids (Gales et al. 1994), about half as much as for harp seal pups (Worthy \& Lavigne 1983a). Thus we assumed that the contribution of lipids per $\mathrm{kg}$ of core (3 MJ, or $75 \mathrm{~g}$ ) was half that found for pups (Worthy \& Lavigne 1983b). We also assumed that lean mass was $70 \%$ water, and that protein catabolism produces $20.1 \mathrm{MJ} \mathrm{kg}^{-1}$ when urea is the end product (Paine 1971). Therefore the energy equivalent of core mass is $8.6 \mathrm{MJ} \mathrm{kg}^{-1}$.

Statistical analyses. Gompertz growth curves of the form

$$
\text { Size }=S_{\infty}\left(\frac{S_{0}}{S_{\infty}}\right)^{\exp \left(\frac{K_{0} \text { Age }}{S_{0} \ln \left(\frac{S_{0}}{S_{\infty}}\right)}\right)}
$$

where $S_{\infty}$ is asymptotic size, $S_{0}$ is size at birth, and $K_{0}$ is growth rate at birth, were fitted to $M_{\mathrm{t}}, M_{\mathrm{S}}, M_{\mathrm{C}}, G$ and $L$ for each time period using the NLIN procedure of SAS (SAS Institute Inc. 1989). This reparameterization of the Gompertz equation by M. C. S. Kingsley (Hammill et al. 1995) makes the parameters easier to interpret biologically. Two other growth curves, the extended Richard's (Hammill et al. 1995) and McLaren's (1993) version of the von Bertalanffy, were fitted to the data, and the degree of divergence between the 3 types of curves was used to diagnose problems with the fit or the data. The fits for the 3 growth curves were similar and only the Gompertz fits are shown in this paper.

McLaren (1993) found it necessary to exclude all pups except newborns in fitting growth curves because of the rapid changes in size taking place during lactation and the postweaning fast found in most young pinnipeds. Because harp seals are born with vir- tually no blubber layer (Blix et al. 1979, Worthy \& Lavigne 1983a, Oftedal et al. 1996, Chabot \& Stenson 2000), we excluded newborns as well, retaining only seals older than 6 mo. Attempts at including newborns or pups often resulted in divergences amongst the 3 types of growth curves, especially for $S_{\infty}$ and an underestimation of size at Ages 1 and $2 \mathrm{yr}$, because of a reduction in $S_{0}$. As a consequence of excluding young seals, we did not interpret $S_{0}$ and $K_{0}$ as the true size or growth rate at birth.

During the February 22 and April 26 periods, when seals were in good and poor condition, respectively (see below), and sample sizes were good, growth is described in more detail for total body mass, and body length. Differences in growth curves between the 2 periods were examined by fitting a model that included period effects for each of the 3 main parameters $\left(S_{\infty}, S_{0}\right.$ and $\left.K_{0}\right)$ using the NLIN procedure of SAS. The age at which growth was essentially complete in these 2 periods was estimated according to 2 techniques. Firstly, we calculated the age at which seals reached $95 \%$ of asymptotic size. Secondly, we calculated the age at which seals completed $95 \%$ of their growth, where growth was the difference between asymptotic size and observed birth size $\left(L=85.7 \mathrm{~cm}, M_{\mathrm{t}}=9.24 \mathrm{~kg}\right.$ : Chabot \& Stenson 2000). Regressions of $L$ and $M_{\mathrm{t}}$ on age were calculated for seals that met these growth criteria. If needed, one year class at a time was removed until the slopes were no longer significant.

In describing the rest of the seasonal cycle, differences in asymptotic size between time periods were assessed by checking whether or not $95 \%$ confidence intervals overlapped. The allometric relationship between masses $\left(M_{\mathrm{t}}, M_{\mathrm{s}}\right.$ and $\left.M_{\mathrm{c}}\right)$ and $L$ was calculated for each period by regression analysis, and the slope compared to the general slope for mammals (3: Peters 1983), using its $95 \%$ confidence interval. In the May 10 
period we tested for a relationship between age class $(1,2,3,4,5,6,7$ and $8+)$ and pelage condition using a contingency table. Condition indices of molted and molting seals were compared by Student's $t$-tests. Regression analyses, contingency table and Student's $t$-tests were conducted using JMP (SAS Institute Inc. 2000).

\section{RESULTS}

\section{Sequential growth curves}

Gompertz growth curves were fitted to $M_{\mathrm{t}}, M_{\mathrm{s}}, M_{\mathrm{C}}$ and $L$ of Phoca groenlandica (Table 2 ) for each period. These curves fitted the data well, and the fitted line was at the center of the size distribution for seals at all ages (e.g. Fig. 2). Age explained a large proportion (50 to $86 \%)$ of the variance in size. The amount of scatter about the fitted lines was small: the SD of residuals was in the range of 10 to $14 \%$ of asymptotic size for mass, and 5 to $6 \%$ for length (Table 2). Finally, the 3 types of growth curves (Gompertz, extended Richard's and von Bertalanffy) were virtually indistinguishable, except for the April 5 period. In general, the Gompertz fits are a good representation of growth and size-at-age in these seals.

There were 2 exceptions when growth curves were less satisfactory, because of truncated age distributions. Firstly, as mentioned above, the 3 types of growth curves diverged during the April 5 period despite high values of $r^{2}(0.52$ to 0.70$)$. This sample con-

Table 2. Phoca groenlandica. Parameters of growth curves (SE) fitted to body, sculp and core mass, and to standard length of male harp seals in each time period. $S_{\infty}$ : asymptotic size; $S_{0}$ : birth size; $K_{0}$ : growth rate at birth. SD of residuals is expressed as \% $S_{\infty}$

\begin{tabular}{|c|c|c|c|c|c|c|c|}
\hline$y$ & Period & $S_{\infty}$ & $S_{0}$ & & $K_{0}$ & $\mathrm{r}^{2}$ & $\mathrm{SD}$ \\
\hline \multirow{10}{*}{$\begin{array}{l}\text { Total mass, } \\
M_{\mathrm{t}}(\mathrm{kg})\end{array}$} & Nov 22 & 117.4 & 32.9 (1.84) & 10.38 & $(0.61)$ & 0.79 & 10.0 \\
\hline & Dec 13 & $114.7(2.66)$ & $32.5(2.30)$ & 11.48 & $(0.69)$ & 0.75 & 10.4 \\
\hline & Jan 07 & 143.5 & $43.7(5.34)$ & 10.94 & $(1.21)$ & 0.74 & 11.3 \\
\hline & Feb 01 & $145.8(3.06)$ & $31.1(3.88)$ & 11.61 & $(0.67)$ & 0.80 & 12.3 \\
\hline & Feb 22 & 149.0 & $30.9(4.66)$ & 14.33 & $(0.67)$ & 0.72 & 11.2 \\
\hline & Mar 15 & $131.0(2.25)$ & $37.8(6.33)$ & 13.38 & $(1.27)$ & 0.63 & 10.6 \\
\hline & Apr 05 & 107.9 & $25.5(9.14)$ & 20.61 & $(5.67)$ & 0.84 & 10.7 \\
\hline & Apr 19 & $109.6(1.48)$ & 31.8 (1.43) & 11.23 & $(0.43)$ & 0.75 & 10.8 \\
\hline & Apr 26 & $102.6(1.04)$ & $34.2(1.28)$ & 11.27 & $(0.45)$ & 0.70 & 11.8 \\
\hline & May 10 & $90.2(3.07)$ & $31.1(1.01)$ & 6.00 & $(0.41)$ & 0.73 & 9.3 \\
\hline \multirow{10}{*}{$\begin{array}{l}\text { Sculp mass, } \\
M_{\mathrm{s}}(\mathrm{kg})\end{array}$} & Nov 22 & $50.1(1.77)$ & $15.0(1.07)$ & 4.16 & $(0.34)$ & 0.69 & 12.4 \\
\hline & Dec 13 & $47.0(1.43)$ & $15.4(1.26)$ & 4.42 & $(0.44)$ & 0.62 & 13.1 \\
\hline & Jan 07 & $64.4(2.54)$ & $20.0(2.57)$ & 4.37 & $(0.57)$ & 0.69 & 12.7 \\
\hline & Feb 01 & $64.4(1.28)$ & $14.2(2.04)$ & 6.34 & $(0.41)$ & 0.76 & 13.3 \\
\hline & Feb 22 & $67.8(0.86)$ & $17.8(2.30)$ & 5.86 & $(0.39)$ & 0.68 & 11.7 \\
\hline & Mar 15 & $61.9(1.01)$ & $17.6(3.56)$ & 7.56 & $(0.78)$ & 0.57 & 11.4 \\
\hline & Apr 05 & $48.8(1.64)$ & $13.5(4.20)$ & 10.24 & $(2.94)$ & 0.85 & 9.4 \\
\hline & Apr 19 & $50.6(0.75)$ & $17.7(0.84)$ & 5.18 & $(0.31)$ & 0.65 & 12.2 \\
\hline & Apr 26 & $47.8(0.53)$ & $18.8(0.72)$ & 5.19 & $(0.29)$ & 0.60 & 13.2 \\
\hline & May 10 & 37.4 (1.41) & $13.4(0.54)$ & 2.75 & $(0.23)$ & 0.65 & 11.5 \\
\hline \multirow{10}{*}{$\begin{array}{l}\text { Core mass, } \\
M_{\mathrm{c}}(\mathrm{kg})\end{array}$} & Nov 22 & $67.4(1.79)$ & $17.9(1.25)$ & 6.19 & $(0.37)$ & 0.77 & 10.7 \\
\hline & Dec 13 & $67.7(1.60)$ & $17.1(1.41)$ & 6.98 & $(0.38)$ & 0.75 & 11.1 \\
\hline & Jan 07 & 78.9 (2.49) & $23.0(3.45)$ & 6.81 & $(0.79)$ & 0.70 & 12.8 \\
\hline & Feb 01 & $81.7 \quad(2.26)$ & $16.1(2.51)$ & 5.55 & $(0.40)$ & 0.74 & 14.9 \\
\hline & Feb 22 & $81.6(1.12)$ & $13.5(3.01)$ & 8.08 & $(0.44)$ & 0.62 & 14.3 \\
\hline & Mar 15 & $69.0(1.83)$ & $18.6(3.93)$ & 6.30 & $(0.63)$ & 0.52 & 14.3 \\
\hline & Apr 05 & $59.0(3.66)$ & $11.9(6.38)$ & 10.47 & $(3.25)$ & 0.71 & 17.0 \\
\hline & Apr 19 & $59.0(0.87)$ & $14.3(0.81)$ & 5.93 & $(0.20)$ & 0.73 & 12.3 \\
\hline & Apr 26 & $54.8(0.61)$ & $15.5(0.77)$ & 5.99 & $(0.24)$ & 0.68 & 13.5 \\
\hline & May 10 & $53.1(2.08)$ & $17.8(0.61)$ & 3.25 & $(0.24)$ & 0.70 & 9.9 \\
\hline \multirow{10}{*}{$\begin{array}{l}\text { Standard length, } \\
L(\mathrm{~cm})\end{array}$} & Nov 22 & 172.9 & $106.5(2.33)$ & 14.75 & $(1.40)$ & 0.77 & 5.3 \\
\hline & Dec 13 & 167.3 & $103.3(2.74)$ & 17.20 & $(1.74)$ & 0.72 & 5.5 \\
\hline & Jan 07 & 174.0 & 112.7 & 13.95 & $(2.50)$ & 0.72 & 5.2 \\
\hline & Feb 01 & $176.6(1.38)$ & $104.3(3.10)$ & 14.95 & $(1.51)$ & 0.82 & 5.2 \\
\hline & Feb 22 & $175.5(0.82)$ & $106.8(3.88)$ & 16.29 & $(1.78)$ & 0.69 & 4.9 \\
\hline & Mar 15 & $173.0(0.83)$ & $107.5(4.66)$ & 18.34 & $(2.32)$ & 0.70 & 3.8 \\
\hline & Apr 05 & $166.5(2.82)$ & 102.6 & 24.49 & (11.39) & 0.86 & 4.6 \\
\hline & Apr 19 & $170.3(0.89)$ & 105.6 & 15.80 & $(0.92)$ & 0.78 & 4.9 \\
\hline & Apr 26 & $170.4(0.60)$ & 107.4 & 16.41 & $(0.73)$ & 0.80 & 4.6 \\
\hline & May 10 & $170.1(2.42)$ & $109.5(1.22)$ & 9.64 & $(0.74)$ & 0.79 & 4.5 \\
\hline
\end{tabular}




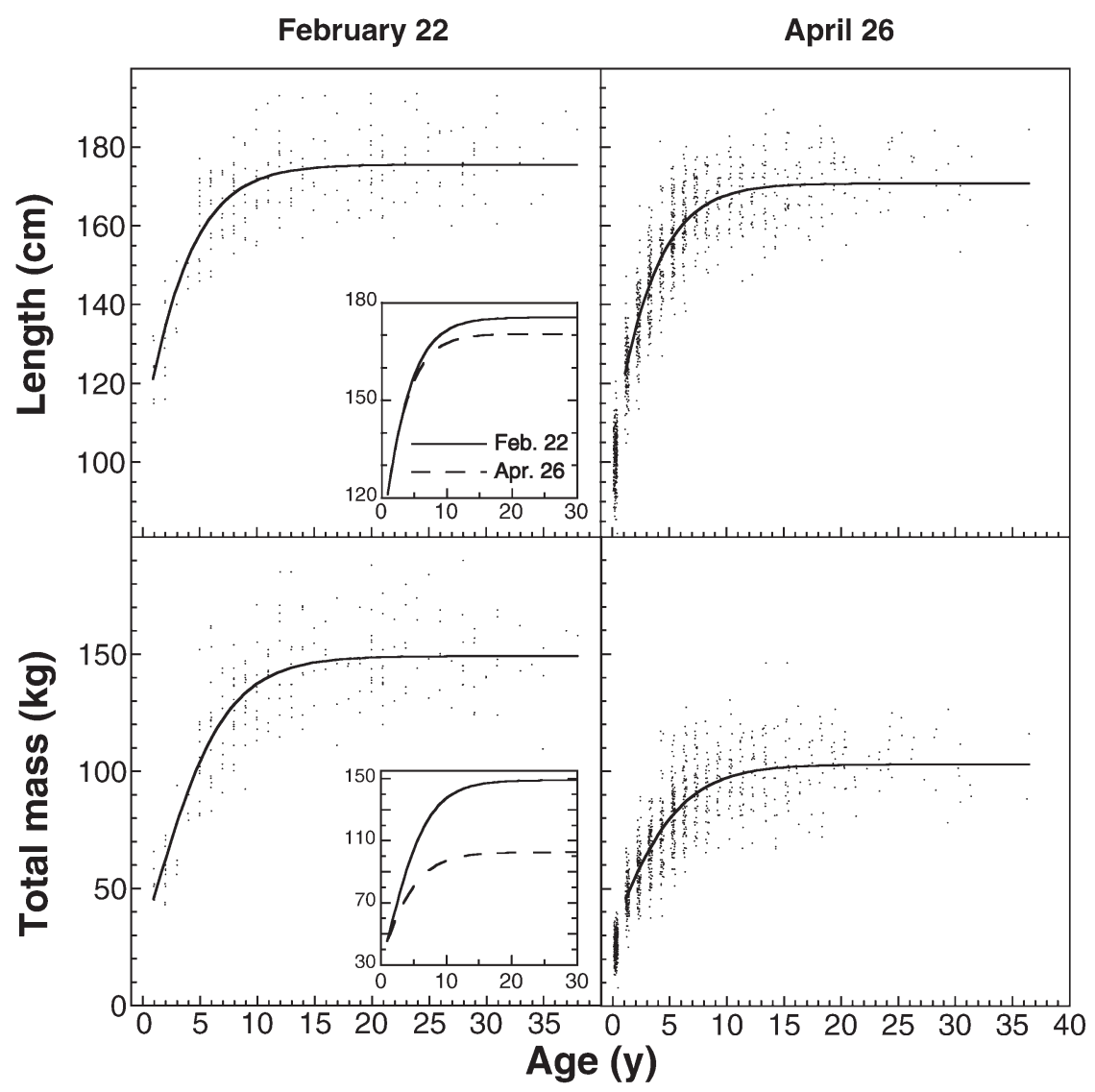

Fig. 2. Phoca groenlandica. Growth in standard length and total mass of males sampled in February 22 period (February 12 to March 4) and April 26 period (April 23 to 29). For April, a small amount of random noise was added to each variable to reduce the overlap arising from measurement roundoff (growth curves were calculated before adding noise). Pups younger than 6 mo are shown on the plots but were excluded from the computation of growth curves. Insets: comparison of growth curves between the 2 periods

tained 20 seals that were 1 yr old, but only 9 that were $\geq 8$ yr. We excluded values for males in the period of April 5 from statistical comparisons. Secondly, there were few seals aged 1 to $3 \mathrm{yr}$ in the sample of January 7 , and these appeared large compared with seals of the same age in the previous and following periods (Fig. 3). The resulting growth curve for January 7 appears to overestimate the size of young seals.

In comparing the changes in $M_{\mathrm{t}}$ estimated by the sequential growth curves to a locally weighted fit on the raw data (Fig. 3), it is clear that estimated values track observations well, with the exceptions noted above. Fig. 3 also confirms that the time periods defined in this study allow us to track seasonal changes in size with a good resolution. Even though the 2 methods produced similar results for young animals, for which large samples were often available, locally weighted fits were based on small sample sizes in most periods for seals $\geq 10 \mathrm{yr}$, and growth curves were more reliable to estimate the size of older seals.

\section{Growth of fat and lean harp seals}

Fig. 2 shows growth in $L$ and $M_{\mathrm{t}}$ of male harp seals for 2 periods: February 22 and April 26. Maximal or near maximal values of $S_{\infty}$ for all variables were observed for the February 22 period, just before females began to give birth. $L_{\infty}$ was $175.5 \mathrm{~cm}$, whereas $M_{\mathrm{t} \infty}$ was $149.0 \mathrm{~kg}$ (Table 2). Male harp seals reached $95 \%$ of their $L_{\infty}$ at Age 8 and completed $95 \%$ of their growth in $L$ at Age 10. However, growth in mass lasted a little longer, and seals reached $95 \%$ of $M_{\mathrm{t} \infty}$ and completed $95 \%$ of their growth in $M_{\mathrm{t}}$ at Age 12 . Regressions of $L$ and $M_{\mathrm{t}}$ stopped being significant when seals younger than Age 12 were excluded.

During the molting season in the April 26 period, male harp seals reached a length of $170.4 \mathrm{~cm}$ and a total mass of $102.6 \mathrm{~kg}$ (Table 2). They grew to $95 \%$ of their $L_{\infty}$ at Age 7 and completed $95 \%$ of their growth in $L$ at Age 9. However a significant regression between $L$ and age was found until seals younger than Age 13 were excluded. Again growth in mass contin- 
ued for approximately 2 yr after final length was attained, as males reached $95 \%$ of $M_{\text {to }}$ and completed $95 \%$ of their growth in $M_{\mathrm{t}}$ at Age 11 . The regression between $M_{\mathrm{t}}$ and age remained significant until seals $<12$ yr were excluded.

Asymptotic values of $M_{\mathrm{t}}, M_{\mathrm{s}}, M_{\mathrm{c}}$ and $L$ were all significantly greater in the February 22 period than in the April 26 period. This seasonal effect was very pronounced for $M_{\mathrm{t}}(42.4 \mathrm{~kg})$, and $57 \%$ of the mass loss between these 2 periods came from the core and only $43 \%$ from the sculp. As a result, the sculp constituted a larger fraction of $M_{\mathrm{t}}$ in the April 26 period (46.5\%) than in the February 22 period (45.5\%), even though seals were in worse condition in April than in February. Growth rate $\left(K_{0}\right)$ was significantly reduced on April 26 compared with February 22 for $M_{\mathrm{t}}$ and $M_{\mathrm{c}}$. The youngest seals did not differ much in size between the 2 periods, but the size of seals increased more rapidly with age in February than in April, as can be seen in Fig. 2 (inset) for $M_{\mathrm{t}}$.

\section{Seasonal fluctuations}

Length

Seals gained in length between their arrival in the study area, during the November 22 period and the February 22 period (Fig. 4a). $L_{\infty}$ did not differ significantly between November 22 and February 22, but this was because of the high variability of our estimate for the November 22 period. Variance was lower for the December 13 period, when $L_{\infty}$ was significantly shorter than for February 22. Seals of all ages increased in $L$ during this interval. $L_{\infty}$ decreased marginally between the periods of February 22 and March 15, but $L$ increased in younger males. $L_{\infty}$ decreased further between the periods of March 15 and April 19, but this was not significant. There was, however, a significant decrease in $L_{\infty}$ between the February 22 and April 19 periods. Seals aged 7 and 10 yr were also shorter during the April 19 period than the February 22 period,

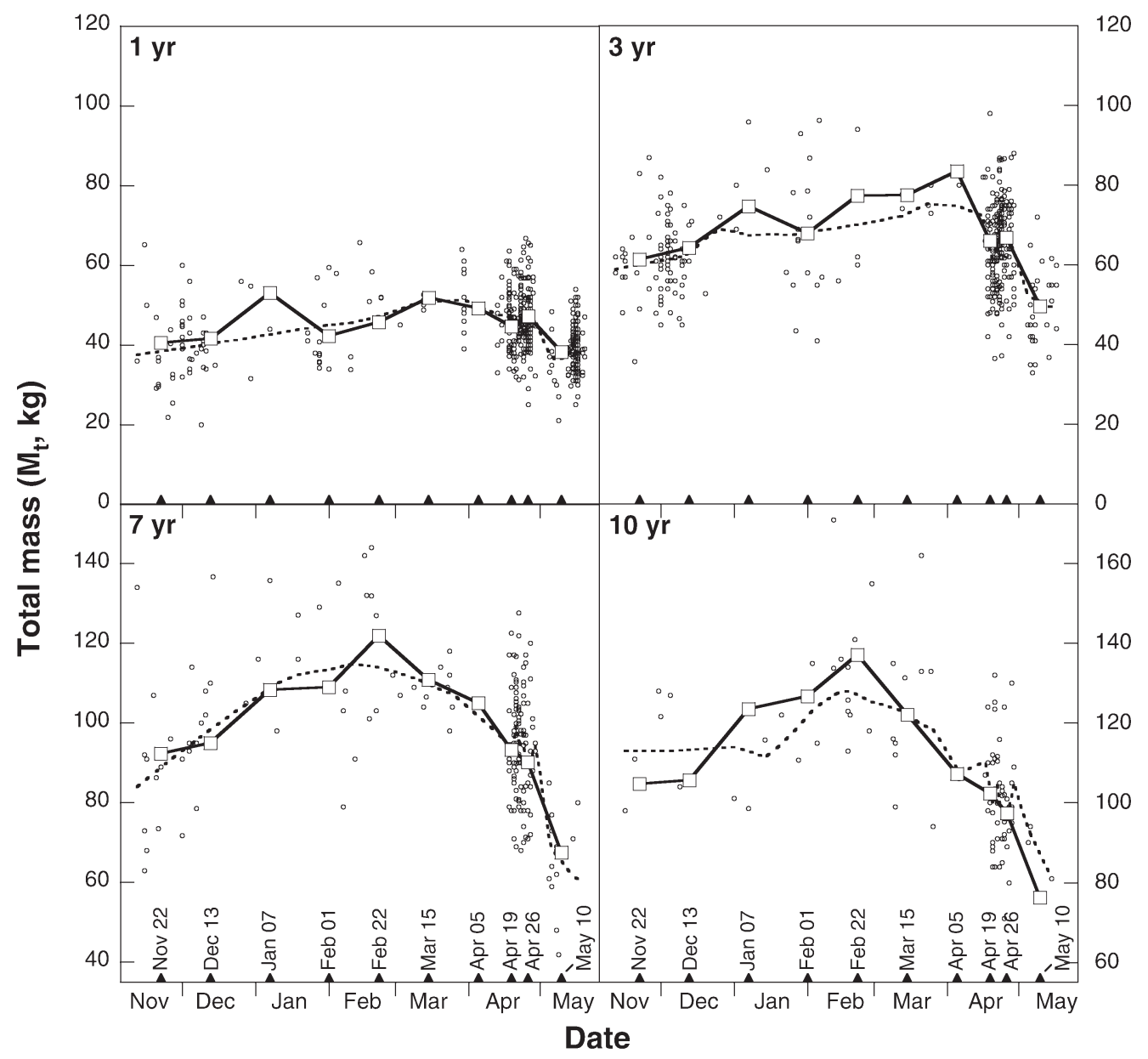

Fig. 3. Phoca groenlandica. Seasonal fluctuations in total body mass of males at 1, 3, 7 and 10 yr. Large symbols, continuous lines: mass estimated from growth curves computed for each time period; small symbols: individual data points; dashed line: locally weighted regression fitted to individual data points 


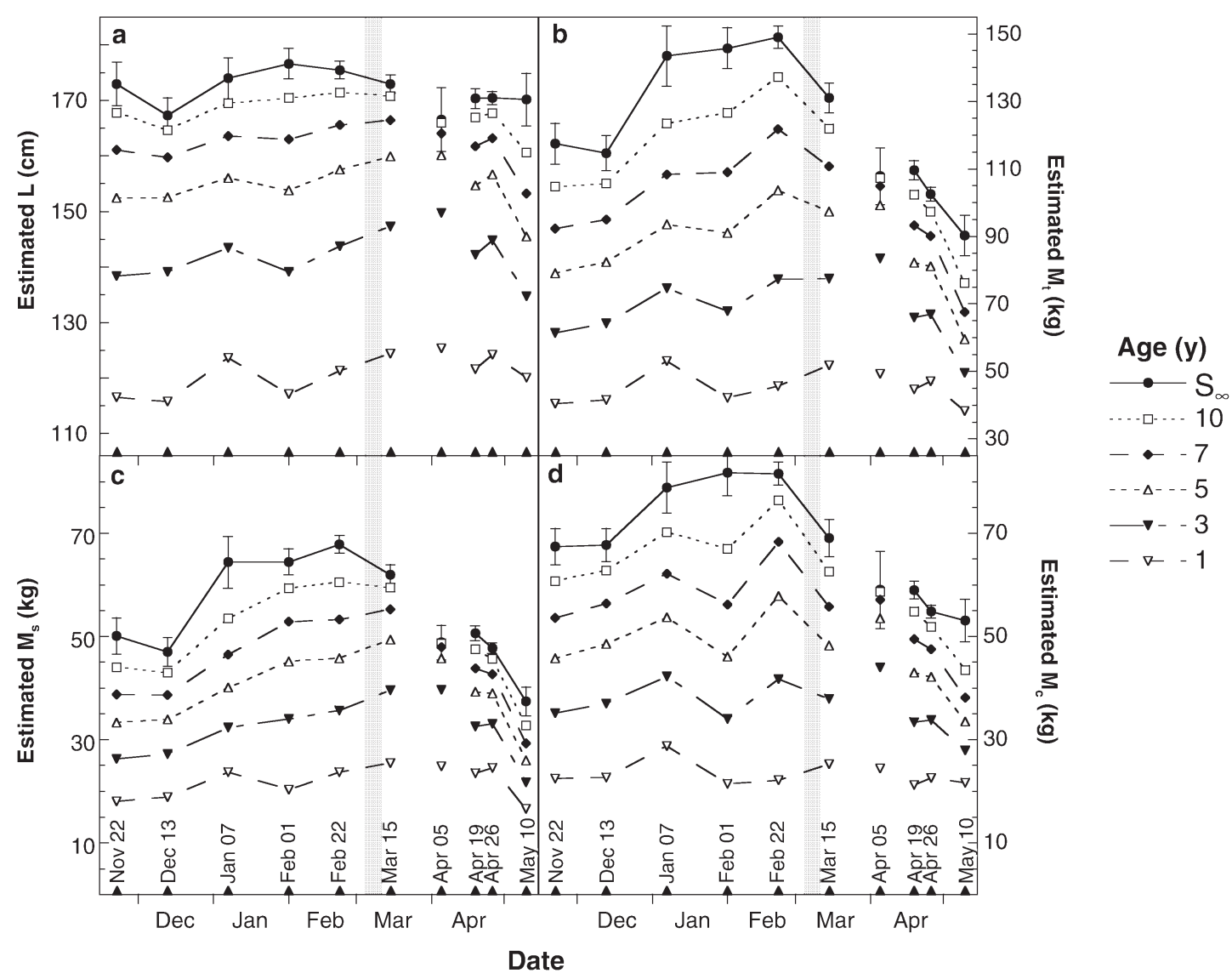

Fig. 4. Phoca groenlandica. Seasonal fluctuations in (a) standard length $(L)$, (b) body mass $\left(M_{\mathrm{t}}\right)$, (c) sculp mass $\left(M_{\mathrm{s}}\right)$, and (d) core mass $\left(M_{\mathrm{c}}\right)$ of male harp seals of $1,3,5,7$, and $10 \mathrm{yr}$, and asymptotic size $\left(S_{\infty}\right)$ with $95 \%$ CI. All values were estimated by Gompertz growth curves fitted to each period. Size on April 5 is shown, but is not considered reliable. Shaded zone represents the peak of the parturition season for the Front (March 4 to 10)

but for younger seals the decline in $L$ started after March 19. $L_{\infty}$ remained small for the rest of the study period. Length did not change much over the summer in seals $\geq 10 \mathrm{yr}$, but increased in younger individuals. In general, males tended to be shortest when they were leanest. $L_{\infty}$ was significantly correlated with $M_{\mathrm{t} \infty}(\mathrm{r}=$ $0.78, \mathrm{p}=0.007), M_{\mathrm{s} \infty}(\mathrm{r}=0.77, \mathrm{p}=0.009), M_{\mathrm{c} \infty}(\mathrm{r}=0.76$, $\mathrm{p}=0.011)$ and $G_{\infty}(\mathrm{r}=0.65, \mathrm{p}=0.04)$.

\section{Mass}

Values of $M_{\mathrm{t}}, M_{\mathrm{s}}$ and $M_{\mathrm{c}}$ observed for the November 22 period were below those observed during the February 22 period (Fig. 4). These differences were significant for $S_{\infty}$, and the gains occurred mostly in December. Males $\leq 10$ yr gained mass more gradually than older males, and males $\leq 5$ yr continued to gain mass until about mid-March. As explained previously, the apparent mass gain in young males on January 7 , followed by a decline on February 1, is probably an arti- fact. Expressed as a percentage of $M_{\mathrm{t}}$ for November 22, mass gains between the November 22 and February 22 periods increased with age up to about $5 \mathrm{yr}$ and remained stable thereafter (Fig. 5a). Sculp and core contributed about equally to mass gained during this interval.

$M_{\mathrm{t} \infty}, M_{\mathrm{s} \infty}$ and $M_{\mathrm{c} \infty}$ decreased significantly between the February 22 and March 15 periods (Fig. 4). Seals $<10$ yr did not lose much mass, and very young seals even gained mass. Most losses were from the core during this interval (Fig. 5b). Because the sample for the April 5 period was small and growth curves unreliable, we looked at changes in size between the March 15 and April 19 periods. All males lost mass during this interval, and the decreases in $M_{\mathrm{t} \infty}, M_{\mathrm{s} \infty}$ and $M_{\mathrm{c} \infty}$ were significant. Males lost about $15 \%$ of initial $M_{\mathrm{t}}$, almost equally from the sculp and the core (Fig. 5c).

$M_{\mathrm{t} \infty}, M_{\mathrm{s} \infty}$ and $M_{\mathrm{c} \infty}$ continued to decline significantly between the April 19 and April 26 periods (Fig. 4). Older males ( $\geq 10 \mathrm{yr}$ ) lost mass at the highest rate observed in this study: about $1 \%$ of $M_{\mathrm{t}} \mathrm{d}^{-1}$, mostly from 
the core $(60 \%$, Fig. 5d). Younger seals, however, lost less mass in proportion to their size ( 5 and 7 yr) or even gained mass ( $\leq 3 \mathrm{yr}$ ). Males of all ages lost mass extensively between the April 26 and May 10 periods, when minimal values of $M_{\mathrm{t}}, M_{\mathrm{s}}$ and $M_{\mathrm{c}}$ were reached (Fig. 4). Seals between 5 and 10 yr lost mass most quickly, but in proportion to their size, all seals $\leq 12 \mathrm{yr}$ lost mass more quickly than old seals (Fig. 5e). Losses of up to $1.8 \%$ of $M_{\mathrm{t}} \mathrm{d}^{-1}$ were estimated for seals aged 3 to 6 yr. Mass losses decreased to about $1 \%$ of $M_{\mathrm{t}} \mathrm{d}^{-1}$ for seals $\geq 20$ yr. Most of the decline occurred in the sculp (60 and $75 \%$ in young and old seals, respectively).

All males gained mass between the May 10 and November 22 periods (Fig. 4), $M_{\mathrm{t} \infty}, M_{\mathrm{s} \infty}$ and $M_{\mathrm{c} \infty}$ were significantly greater for the November 22 period than in early May. In proportion to their size, seals between 3 and 7 yr gained most in mass (more than $40 \%$ of $M_{\mathrm{t}}$, Fig. 5f). Seals replenished energy stores mostly in their core tissues, as shown by the greater increase in $M_{\mathrm{c}}$ than in $M_{\mathrm{s}}$.

\section{Allometric equations}

Table 3 gives the relationship between mass $\left(M_{\mathrm{t}}, M_{\mathrm{s}}\right.$ and $M_{\mathrm{c}}$ ) and $L$ for the entire study period and for each period. For $M_{\mathrm{t}}$, the slope was significantly less than 3 except for February 1 and April 5. For $M_{\mathrm{C}}$ the slope
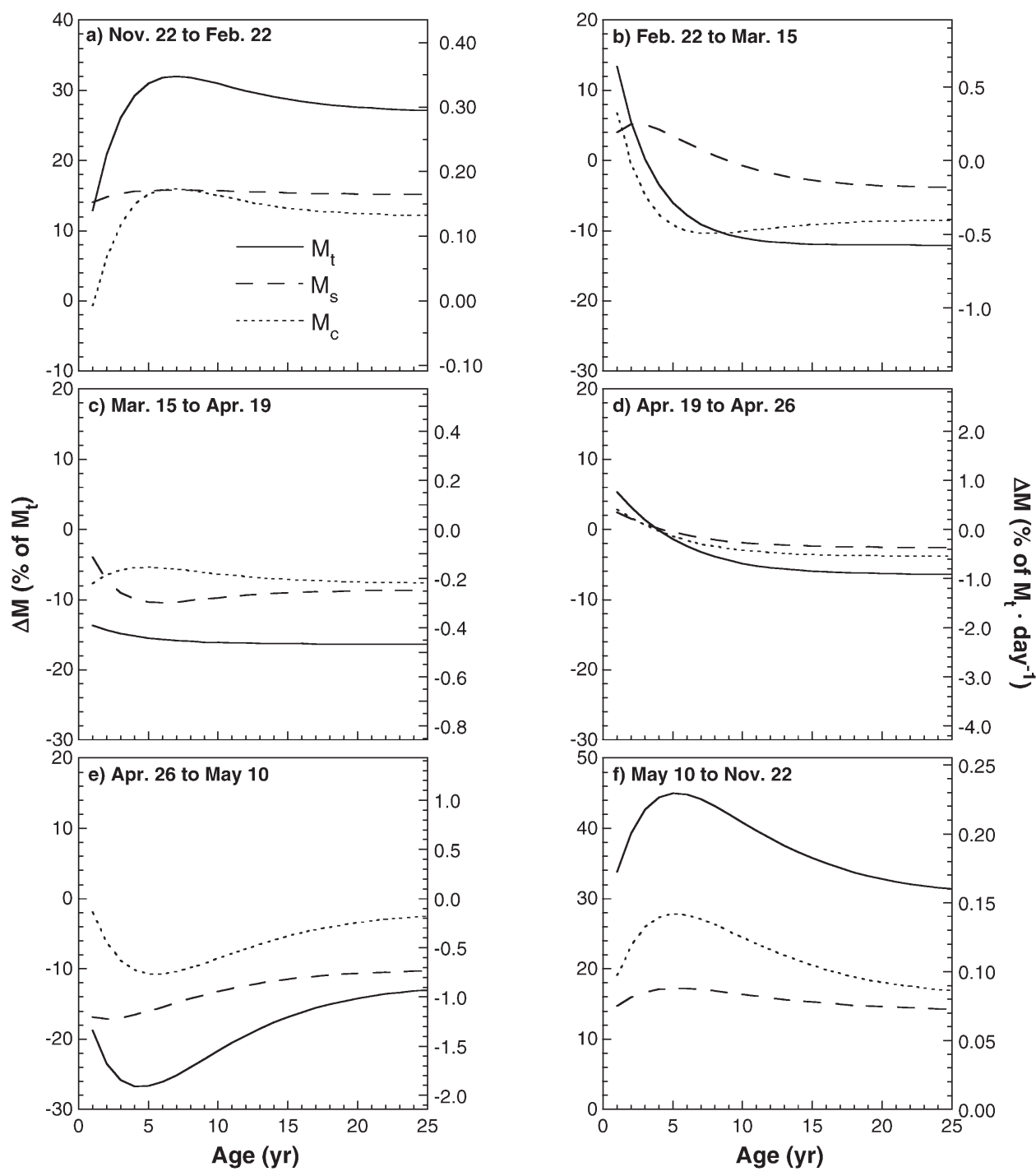

Fig. 5. Phoca groenlandica. Relationship between changes in mass (total, sculp and core) and age for males during the main periods identified in this study: (a) early winter, (b) reproduction, (c) pre-molt, (d) molt, (e) late molt and (f) summer. All mass changes were calculated from growth curves and expressed in \% of total mass at the beginning of each period. Right axis expresses 
differed significantly from 3 from February 22 to April 5. The slope was always smaller than 3 for $M_{\mathrm{s}}$. In all cases, length explained a large part of the variability in mass $\left(M_{\mathrm{t}}: 0.79 \leq \mathrm{r}^{2} \leq\right.$ $0.95 ; M_{\mathrm{s}}: 0.68 \leq \mathrm{r}^{2} \leq 0.88 ; M_{\mathrm{c}}: 0.70 \leq$ $\left.\mathrm{r}^{2} \leq 0.92\right)$.

\section{Condition, blubber thickness and ratio of sculp to total mass}

Male harp seals sampled in November were below their peak condition, which was reached in February for older seals, and in March for seals $\leq 5$ yr (Fig. 6a). Core condition was almost constant during this interval (Fig. 6c), and improvements in sculp condition and blubber thickness, $B$ (Fig. 6b,d), were mostly responsible for the improving general condition. Therefore the sculp became an increasingly larger proportion of $M_{\mathrm{t}}$ during this interval (Fig. 6e). A decline in condition of older males commenced in late February. This decline continued at a constant rate until the end of the study period in May. In younger seals, no decrease in condition or $B$ were observed until April, but the decreases were then faster than in older seals. The decline was faster in sculp than in core condition for seals of all ages. The minimum values for all 3 condition indices and $B$ were observed in May for seals of all ages

The sculp continued to become a larger proportion of $M_{\mathrm{t}}$ until the beginning of April, when this proportion started to decrease rapidly. The apparent increase in $B$ between late April and mid-May for $10 \mathrm{yr}$ old males, and the increase in core condition for 7 and $10 \mathrm{yr}$ old males during the same interval, were not corroborated by the other variables (Fig. 6). They were probably the result of small sample sizes and non-representative individuals. All seals improved in general condition between May and November. Although sculp condition improved and $B$ increased, core condition improved the most and was replenished almost to peak values. As a result, the ratio of $M_{\mathrm{s}}$ to $M_{\mathrm{t}}$ was lowest in November. The amplitude of these cycles for condition indices and $B$ increased with age, but this was not the case for the ratio of $M_{\mathrm{s}}$ to $M_{\mathrm{t}}$.
Table 3. Phoca groenlandica. Mass-length relationships (after $\log _{10}$ transformation) for male harp seals during each period of the yearly cycle between midNovember and mid-May

\begin{tabular}{|c|c|c|c|c|}
\hline$y$ & Intercept (SE) & Slope (SE) & Slope $\neq 3$ & $\mathrm{r}^{2}$ \\
\hline \multicolumn{5}{|l|}{$M_{\mathrm{t}}$} \\
\hline All periods & $-4.170(0.044)$ & $2.783(0.020)$ & Yes & 0.86 \\
\hline Nov 22 & $-3.586(0.134)$ & $2.512(0.062)$ & Yes & 0.88 \\
\hline Dec 13 & $-3.524(0.150)$ & $2.491(0.069)$ & Yes & 0.84 \\
\hline Jan 07 & $-3.749(0.266)$ & $2.616(0.121)$ & Yes & 0.83 \\
\hline Feb 01 & $-4.605(0.127)$ & $3.004 \quad(0.058)$ & No & 0.95 \\
\hline Feb 22 & $-4.059(0.188)$ & $2.771(0.085)$ & Yes & 0.82 \\
\hline Mar 15 & $-3.831(0.236)$ & $2.648(0.106)$ & Yes & 0.79 \\
\hline Apr 05 & $-3.972(0.355)$ & $2.700(0.166)$ & No & 0.90 \\
\hline Apr 19 & $-3.488(0.079)$ & $2.467(0.036)$ & Yes & 0.87 \\
\hline Apr 26 & $-3.394(0.064)$ & $2.416(0.030)$ & Yes & 0.87 \\
\hline May 10 & $-3.148(0.123)$ & $2.274(0.058)$ & Yes & 0.83 \\
\hline \multicolumn{5}{|l|}{$\boldsymbol{M}_{\mathrm{s}}$} \\
\hline All periods & $-4.216(0.057)$ & $2.651(0.026)$ & Yes & 0.77 \\
\hline Nov 22 & $-3.792(0.194)$ & $2.435(0.089)$ & Yes & 0.76 \\
\hline Dec 13 & $-3.529(0.204)$ & $2.318(0.094)$ & Yes & 0.70 \\
\hline Jan 07 & $-3.903(0.334)$ & $2.521(0.152)$ & Yes & 0.74 \\
\hline Feb 01 & $-4.218(0.179)$ & $2.680(0.081)$ & Yes & 0.88 \\
\hline Feb 22 & $-3.982(0.202)$ & $2.580(0.091)$ & Yes & 0.77 \\
\hline Mar 15 & $-3.612(0.285)$ & $2.409(0.128)$ & Yes & 0.68 \\
\hline Apr 05 & $-3.417(0.352)$ & $2.295(0.164)$ & Yes & 0.87 \\
\hline Apr 19 & $-3.048(0.101)$ & $2.119(0.046)$ & Yes & 0.75 \\
\hline Apr 26 & $-3.011(0.084)$ & 2.096 (0.039) & Yes & 0.75 \\
\hline May 10 & $-3.304(0.172)$ & $2.176(0.081)$ & Yes & 0.69 \\
\hline \multicolumn{5}{|l|}{$\boldsymbol{M}_{\mathrm{c}}$} \\
\hline All periods & $-4.736(0.051)$ & $2.916(0.023)$ & Yes & 0.83 \\
\hline Nov 22 & $-3.974(0.141)$ & $2.580(0.065)$ & Yes & 0.87 \\
\hline Dec 13 & $-4.070(0.166)$ & $2.634(0.077)$ & Yes & 0.82 \\
\hline Jan 07 & $-4.203(0.291)$ & $2.709(0.132)$ & Yes & 0.81 \\
\hline Feb 01 & $-5.535(0.173)$ & $3.299(0.079)$ & Yes & 0.92 \\
\hline Feb 22 & $-4.753(0.247)$ & $2.965(0.111)$ & No & 0.75 \\
\hline Mar 15 & $-4.611(0.310)$ & $2.867(0.140)$ & No & 0.72 \\
\hline Apr 05 & $-5.153(0.799)$ & $3.111(0.373)$ & No & 0.70 \\
\hline Apr 19 & $-4.505(0.088)$ & $2.801(0.040)$ & Yes & 0.87 \\
\hline Apr 26 & $-4.350(0.077)$ & $2.721 \quad(0.035)$ & Yes & 0.86 \\
\hline May 10 & $-3.557(0.130)$ & $2.349(0.061)$ & Yes & 0.82 \\
\hline
\end{tabular}

Pelage condition

Male harp seals had a clearly marked seasonal pattern of pelage condition (Table 1). Essentially all seals had fast hair from November through March. Pelage condition was measured for only 7 males in the April 5 period, and all had fast hair. A change came very suddenly in the April 19 period, when the vast majority of seals (682 out of 689 , or $99 \%$ ) had loose hair. All seals were molting in the April 26 period. Only in the May 10 period did we find seals that had completed their molt (46\%: Table 1). There was a tendency for the proportion of molted seals to be lower in seals aged 1 and 2 yr (Table 4 ), but this was not significant, as the ratio of molted to molting seals did not differ according to year class $\left(\chi^{2}{ }_{[7]}=3.6, \mathrm{p}=0.82\right)$. Seals that had completed their molt were in worse general condition than seals that were still molting 


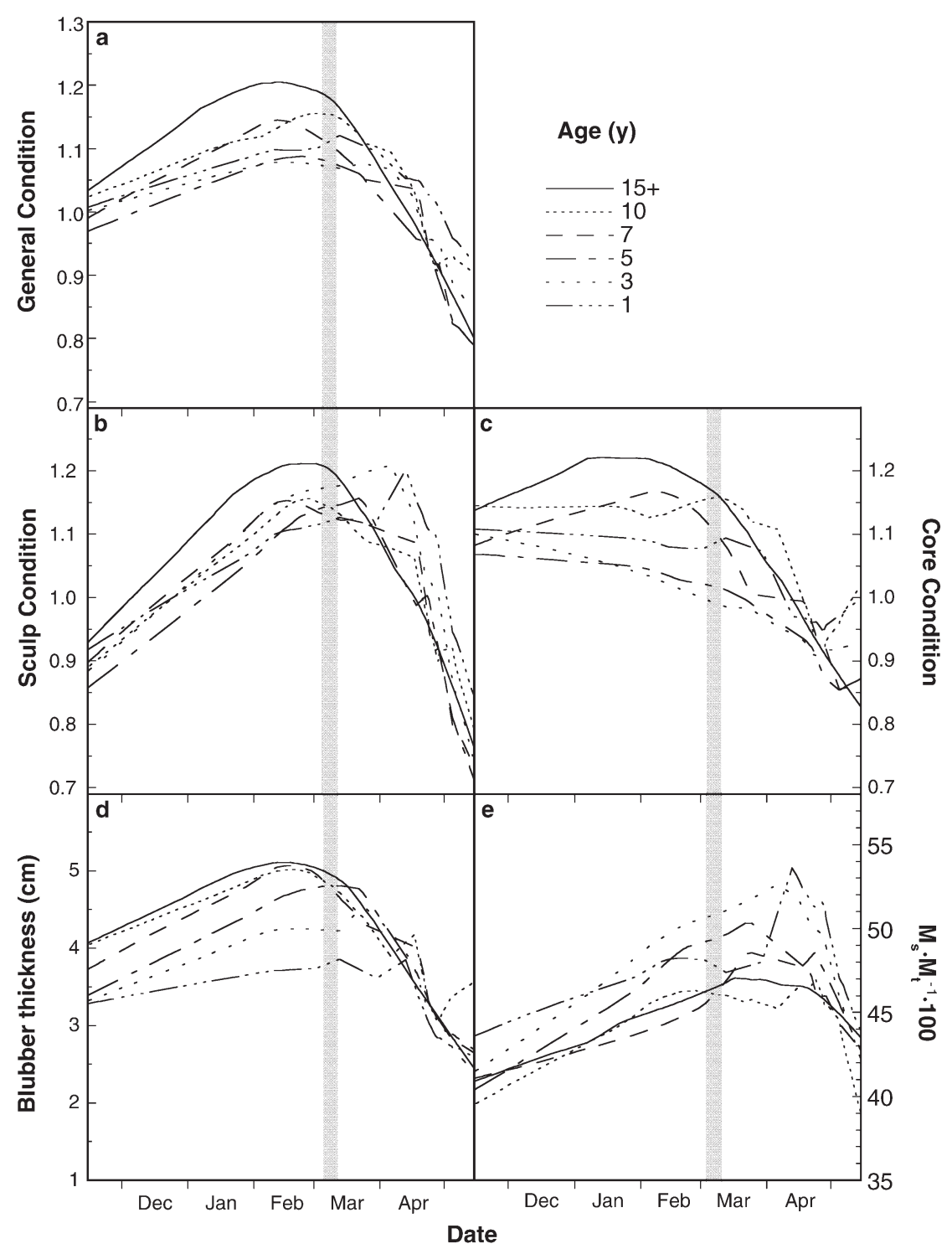

Fig. 6. Phoca groenlandica. Seasonal changes in (a) general, (b) sculp and (c) core condition, (d) in blubber thickness and (e) in the ratio of sculp to total mass of males of 1,3, 5, 7, 10 and 15+ yr. Individual data points are not shown in order to reduce clutter. Fitted lines are locally weighted fits

$\left(t_{[316]}=-4.2, \mathrm{p}<0.0001\right)$. This was true also for sculp condition $\left(t_{[316]}=-7.1, \mathrm{p}<0.0001\right)$, but not for core condition $\left(t_{[316]}=-0.78, \mathrm{p}=0.43\right)$.

\section{DISCUSSION}

\section{Advantages of growth curves to describe seasonal cycles}

In cross-sectional studies, seasonal variations in size for seals of a given age are usually difficult to measure because of inadequate sample sizes, especially in older seals. To solve this difficulty, seals of similar age are usually grouped together and mean size or condition is compared between seasons (Sivertsen 1941, Sergeant 1973, Beck et al. 1993, Beck \& Smith 1995, Nilssen et al. 1997). This, however, can introduce bias if the age distribution within an age class is different for each season. Condition indices that correct for seal length reduce the impact of differences in age distribution between seasons, but do not eliminate it: 3 such indices were affected by age in this study on Phoca groenlandica. Even if one was interested in tracking seasonal changes only in mature seals, it is unclear which cutoff value should be used in defining mature seals, as we have shown that 3 estimates of the age at which growth stopped differed for the same variable in the 
Table 4. Phoca groenlandica. Number and proportion of male harp seals of different age classes that were molting or had completed their molt in the May 10 period. Age class as in Table 1

\begin{tabular}{|lrrrr|}
\hline \multirow{2}{*}{ Age class } & \multicolumn{2}{c}{ Molted } & \multicolumn{2}{c|}{ Molting } \\
& $\mathrm{n}$ & $\%$ & $\mathrm{n}$ & $\%$ \\
\hline 1 & 57 & 42.2 & 78 & 57.8 \\
2 & 20 & 40.8 & 29 & 59.2 \\
3 & 13 & 48.1 & 14 & 51.9 \\
4 & 12 & 50.0 & 12 & 50.0 \\
5 & 12 & 52.2 & 11 & 47.8 \\
6 & 8 & 50.0 & 8 & 50.0 \\
7 & 8 & 61.5 & 5 & 38.5 \\
$8+$ & 16 & 51.6 & 15 & 48.4 \\
\hline
\end{tabular}

same time period, and between variables or periods. This bias could be removed by selecting seals old enough to insure that growth was complete for all variables and all time periods. This, however, would greatly reduce sample sizes.

Sequential growth curves take advantage of the information contained in the data from seals of all ages to estimate size-at-age. They make it possible to estimate size for individuals of any age, in any time period. The use of growth curves accounted for the effect of age, but not length, on seal size. While growth curves made use of information from seals of all ages, locally weighted regressions on condition indices, $B$ and the ratio of $M_{\mathrm{s}}$ to $M_{\mathrm{t}}$ used information from seals of a given age sampled in adjacent time periods, making them a useful complement to the sequential growth curves.

\section{Growth and seasonal fluctuations in length}

Length is generally seen as the best measure of size to describe growth in pinnipeds (Laws 1959, McLaren 1993). But we have shown that the body length of harp seals is also subject to significant seasonal fluctuations. Possibly the shorter lengths at age (observed in April and May) could result from a sampling bias if low-quality individuals were sampled at this time. We do not believe this to be the case. Harp seals molt in a small number of large aggregations, and each year that molting seals were sampled, at least 1 of the major aggregations was sampled. Interestingly, Sivertsen (1941) observed a decline in length of 'saddle' (i.e. mature) Northeast (NE) Atlantic harp seal males from early March $(175.3 \mathrm{~cm}, \mathrm{n}=39)$ to late April $(171.9 \mathrm{~cm}, \mathrm{n}=39)$ and late May $(166.7 \mathrm{~cm}, \mathrm{n}=6)$. He attributed this decline to inadequate sample sizes, but our results suggest the decline was real. The amplitude of the oscillation in length was $5.2 \mathrm{~cm}$ (about $3 \%$ ) in our study, which is as much as the difference in length between male and female harp seals (Sivertsen 1941, Hammill et al. 1995, Kjellqwist et al. 1995). Seasonal oscillations in length have been reported also for northern fur seals Callorhinus ursinus (McLaren 1993, Trites \& Bigg 1996). The reasons for these fluctuations are not clear. Fisher (1954) mentioned that fatness could affect how the length of harp seals is measured: a thick blubber layer could result in a tightening of the skin which 'pulled in' the seals so that they did not stretch out as much when laid out on the ground. However the changes in length observed in the present study were in the opposite direction: there was a significant positive correlation between asymptotic $L$ and $M_{\mathrm{s}}$. Fat northern fur seals were also longer than thin ones (Trites \& Bigg 1996). These authors suggested that body mass might exert more stress upon the vertebral column of a fat seal than of a thin seal, resulting in an apparent increase in $L$. It is also possible that length measurements of seals, which are greatly influenced by neck extension, are on average greater if an accumulation of blubber forces the neck to be more extended.

Pooling data from different seasons to compute growth in length of harp seals produces at best an average growth curve for all seasons, or at worst a growth curve that is biased by the distribution of the data. The comparison of growth in length between sexes or between studies, could be impaired if the seasonal coverage for each sex or each study differed. Thus we expected that $L_{\infty}$ from other studies of northwest (NW) Atlantic male harp seals would fall between the extremes found in our own $(175.5$ and $170.4 \mathrm{~cm}$ in February and April). This was true for recent studies, which used growth curves. Thus $L_{\infty}$ was estimated to be $169.9 \mathrm{~cm}$ for the late 1970s (Innes et al. 1981) and $170.4 \mathrm{~cm}$ for the period 1988 to 1992 (Hammill et al. 1995). These values were not significantly different (Hammill et al. 1995). They are close to our lower estimate, owing to the majority of seals having been sampled in March and April. Older studies obtained lower values. Mean length of old males was estimated to be between 158 and $161 \mathrm{~cm}$ in the 1950s (Fisher 1954, Laws 1959), and between 163.5 and $167.1 \mathrm{~cm}$ in the late 1960s (Sergeant 1991). However, mean length will often underestimate $L_{\infty}$ unless a large proportion of very old seals is included. In addition, these estimates were based on small (around 20) sample sizes.

Khuzin (1963, cited in Sergeant 1991) considered that harp seals from the White Sea were longer than those from the NW Atlantic. Sivertsen (1941) obtained a mean length of $172 \mathrm{~cm}$ for male 'saddle' harp seals collected in the White Sea between 1925 and 1937. Sergeant (1991), correcting Khuzin's original measurements from the early 1960s, made along the curve of the back, calculated a mean standard length of $171.1 \mathrm{~cm}(\mathrm{n}=100)$. These findings support Khuzin's 
contention, but considering the small samples, especially for the NW Atlantic, and possible differences in seasonal coverage and age distribution between studies (all 'saddle' seals were usually considered 'mature'), this is not conclusive. Kjellqwist et al. (1995) calculated $L_{\infty}$ for NE Atlantic male harp seals using growth curves. Their estimates of $174.1 \mathrm{~cm}$ for 1963 to 1972 and $165.8 \mathrm{~cm}$ for 1990 to 1993 (this difference was not significant) are not greater than our own. Therefore, a difference in length between these 2 populations remains to be demonstrated.

\section{Seasonal changes in mass, condition, blubber thickness, and ratio of sculp to total mass}

$$
\text { Fall and early winter }
$$

Male harp seals collected in November were below their peak in size, condition, and $B$, which were observed in late February or even later for young seals. Sergeant (1973) also reported gains in $B$ and Smirnov's condition index between fall and winter, and Beck et al. (1993) reported increases in $M_{\mathrm{t}}$ and $M_{\mathrm{S}}$ between early winter and the whelping season. It is clear that harp seals feed in waters off southern Labrador and Newfoundland and in the Gulf of St Lawrence between November and late February. Hedd et al. (1997) suggested that the basal metabolic rate (BMR) of harp seals might be lower at this time, which would help seals gain mass. This must be interpreted with caution, however, because their captive harp seals tended to be much fatter than wild ones and did not display the same patterns of mass change as wild ones (see Renouf et al. 1993, Renouf \& Gales 1994).

Gains made during this period were distributed almost equally between sculp and core mass. However, increases in $M_{\mathrm{c}}$ appeared to be a result of increasing length, because core condition did not increase as much as sculp condition, and the ratio of $M_{\mathrm{s}}$ to $M_{\mathrm{t}}$ increased markedly during this interval. By late February, $M_{\mathrm{t} \infty}, M_{\mathrm{s} \infty}$ and $M_{\mathrm{c} \infty}$ reached 149.0, 67.8 and $81.6 \mathrm{~kg}$, respectively. These values are greater than those of Sergeant $\left(1991\right.$, p. $\left.25 ; M_{\mathrm{t}}=130 \mathrm{~kg}\right)$ and Innes et al. $\left(1981 ; 129.9,61.5\right.$, and $70.3 \mathrm{~kg}$ for $M_{\mathrm{t} \infty}, M_{\mathrm{s} \infty}$ and $M_{\mathrm{c} \infty}$ in growth curves for both sexes combined), probably because these authors pooled seals sampled over several months.

\section{Reproduction period}

Males congregate in the whelping areas before whelping begins and produce a strong rank smell that has been associated with the rutting state (Sergeant
$1965,1991)$. The onset of sperm production can be as early as January (Fisher 1954), and testicular size peaks in February and March (Miller et al. 1998). We showed that males began to lose mass between the February 22 and March 15 periods, and that condition and $B$ started to decrease before the end of February. Late February can therefore be considered the beginning of the rut in male harp seals from this population. Yet most females mated after March 19, after they had completed their 12 d nursing period (Kovacs \& Lavigne 1985, Ouellette \& Ronald 1985, Sivertsen 1941, Sergeant 1991). Thus males are in the rutting state and reduce their feed intake about $3 \mathrm{wk}$ before most copulations take place, probably to insure that they can service females that whelp early or barren females that may come in estrus before reproducing females.

Fisher (1954) observed a decline in spermatogenic activity after March 28 and suggested that this was the end of the mating season, or at least of the peak of the mating season. Therefore the rate of mass loss in breeding males probably diminishes at that time. Unfortunately we were unable to compute reliable growth curves during the April 5 period and assumed a linear rate of change of mass between the March 15 and April 19 periods. We did observe a steady rate of decline in condition over this interval, but this analysis also suffered from a small sample size in late March and early April.

Considering that Sergeant (1973) reported a stable condition in adult males between late March and midApril, we could assume that mass on March 28 was the same as mass observed on April 19. Thus males lost $1.16 \mathrm{~kg} \mathrm{~d}^{-1}\left(0.78 \%\right.$ of $\left.M_{\mathrm{t}} \mathrm{d}^{-1}\right)$, for a total of $39.4 \mathrm{~kg}(26 \%$ of initial mass) during the breeding period. This falls within the range for northern elephant seals $\left(0.4 \% \mathrm{~d}^{-1}\right.$; Walker \& Bowen 1993), gray seals (0.9 to $1.0 \% \mathrm{~d}^{-1}$; Anderson \& Fedak 1985, Tinker et al. 1995), Antarctic fur seals $\left(0.8 \% \mathrm{~d}^{-1}\right.$; Walker \& Bowen 1993), and harbor seals $\left(0.8\right.$ to $0.9 \% \mathrm{~d}^{-1}$; Reilly \& Fedak 1991, Walker \& Bowen 1993). Of these species, the behavior of male harbor seals is most similar to that of harp seals, and rates of mass loss appear similar.

The degree of mass loss is a reflection of reproductive effort in species which stop or reduce feeding during the breeding season. Because of interspecific differences in the ratio of lipids to proteins used as fuel (Worthy \& Lavigne 1987, Deutsch et al. 1990, Walker \& Bowen 1993), similar rates of mass loss can translate into different rates of energy expenditure. Declines in sculp and core masses contributed 44 and 56\%, respectively, to the decline in $M_{\mathrm{t}}$ estimated for the breeding season. Therefore, males were producing 21.3 MJ for each $\mathrm{kg}$ they lost, and lipids provided $85 \%$ of this energy. This corresponds to $24.7 \mathrm{MJ} \mathrm{d}^{-1}$, or $840 \mathrm{MJ}$ for the breeding season. This is only 2 times the standard 
metabolic rate (SMR) as estimated from the general allometric relationship for mammals (Kleiber 1975). This is a low value for the average daily metabolic rate $(\mathrm{ADMR}=\mathrm{SMR}+$ cost of digestion, growth and activity), especially considering that males are very active at this time. They often swim rapidly, sometimes in pursuit of females, and fight frequently among each other or with females which are not ready to mate (Sivertsen 1941, Nazarenko 1975, Merdsoy et al. 1978). Male harbor seals have a similar behavior during the breeding season (Sullivan 1981, Thompson 1988, Reilly \& Fedak 1991, Walker \& Bowen 1993). As a result, their metabolism can be as high as 6 times the BMR during the breeding period (Reilly \& Fedak 1991). This suggests that we underestimated mass losses due to breeding. This could be due to a regain in mass between the end of breeding and mid-April, since this would have increased mass for the April 19 period, which we used as an estimate of mass at the end of the breeding season. However, increases in mass or feeding intensity of males have never been documented for this time of the year, and rutting males could instead ingest significant quantities of food during the breeding season. It has been shown that nursing females do feed at this time (Stewart \& Murie 1986, Lydersen \& Kovacs 1993, 1996), confirming that prey are available.

Very young males (1 and 3 yr), which are not sexually mature (Fisher 1954, Miller et al. 1998) did not lose mass between the February 22 and March 15 periods, but were lighter in the April 19 period. We cannot ascertain when they lost mass, but our analysis of the changes in condition suggests that they did not lose mass until the end of March. This agrees with the findings of Walker \& Bowen (1993), who observed that subadult harbor seals did not lose mass during the breeding period. Males aged between 5 and 10 yr lost mass in the early part of the breeding season, and their condition declined markedly in March. These changes increased with age, probably because of the increasing rate of sexual maturity with age (Fisher 1954, Miller et al. 1998).

Changes in size and the condition indices appear to disagree for the breeding period. Losses in core mass were more important than those in sculp mass, yet core condition declined more slowly than sculp condition. This is because sculp mass was almost always less than core mass, and the indices involved the average sculp or core mass expected for a given length. Changes in mass that involved smaller changes in $M_{\mathrm{s}}$ (in absolute terms) than in $M_{\mathrm{c}}$ could therefore result in greater changes in sculp condition than in core condition. The ratio of $M_{\mathrm{s}}$ to $M_{\mathrm{t}}$ cannot be considered a condition index, however, because it can increase when energy reserves decrease, if $M_{\mathrm{c}}$ decreases faster than $M_{\mathrm{s}}$ as was the case during the rut. The decreases in $M_{\mathrm{c}}$ observed during the rut are nonetheless remarkable. They could constitute a mechanism for heat conservation when air temperatures are very low. Ryg et al. (1988) suggested that the best insulative value of blubber is obtained when the ratio of blubber thickness to body radius remains close to an optimal value, and thus reductions in blubber thickness should be accompanied by reduction in core radius.

\section{Molting}

Seals lost mass between the March 15 and April 19 periods, but we cannot discriminate between mass losses due to reproduction and those due to the molt, if any, for sexually mature seals. Very young males, however, were not likely to have been involved in reproduction, and yet they lost 7 to $15 \%$ of $M_{\mathrm{t}}$, mostly from the sculp, between March 15 and April 19. Sergeant (1965) reported that immature harp seals and mature males began their molt in late March. We only observed harp seals with loose hair after April 16 (first day of the April 19 period). We suggest that aggregations of male harp seals seen from late March to midApril are in pre-molt, a state in which hair loss has not yet started. Harp seals should be in negative energy balance at this time, because of the reduction in feeding opportunities due to the amount of time hauled out on ice (Sivertsen 1941, Sergeant 1973, 1991). It has been suggested that this behavior allows the skin to warm up sufficiently to permit the mitosis necessary for the growth of new hair (Feltz \& Fay 1966), without the high energetic demand that would be required to keep the skin warm while remaining in water (Boily 1995).

The onset of molting was very sudden, for practically all males sampled in the April 19 and April 26 periods were losing hair. About half of them had completed their molt at the end of the study. A molting duration of 1 mo or more agrees with Sivertsen's (1941) findings for harp seals. Molting durations of 30 to $36 \mathrm{~d}$ have been reported for harbor seals (Reilly \& Fedak 1991), northern elephant seal females (Worthy et al. 1992), and southern elephant seal males (Slip et al. 1992).

Males $\geq 10$ yr lost mass at rates of about $1 \%$ of $M_{\mathrm{t}} \mathrm{d}^{-1}$ between the April 19 and 26 periods, and again between the April 26 and May 10 periods. Between the April 19 and April 26 periods, about $60 \%$ of mass losses were from the core. The situation was reversed between the April 26 and May 10 periods, when $75 \%$ of the losses were from the sculp. Possibly core lipids were exhausted, or core proteins could no longer be spared. The lowest values of mass, condition and $B$ were measured in the May 10 period, and seals that 
had completed their molt were in worse general and sculp condition than those that were still molting. The pattern of mass loss was different in younger seals. The mass of males $\leq 5 \mathrm{yr}$, which was declining up to the period of April 19, remained stable or even increased slightly between the April 19 and 26 periods, and then resumed a rapid decline (up to $1.5 \%$ of $M_{\mathrm{t}} \mathrm{d}^{-1}$ ) between the April 26 and May 10 periods. Despite the stable or increasing mass between the April 19 and 26 periods, the condition of these young males deteriorated (in part because of a concurrent increase in length) and $B$ decreased. These changes could reflect the late arrival at the molting patches of young males, possibly of larger size than average. It is known that in late April there is an influx of immature seals and old females to the molting patches already occupied by mature males (Sergeant 1965). These young males arriving late appear delayed in their molt, because we observed a tendency for a lower proportion of young males than of older males to have completed their molt in the period of May 10. This is unlike harbor seals: reproducing males tend to molt later than nonreproducing males (Thompson \& Rothery 1987).

The uncertainties pertaining to the beginning and end of the molt made it impossible to determine the total decline in mass or the energy expenditure for the entire pre-molt and molting periods. However, it is clear that seals of all age groups experienced periods of high energy expenditure during the molt, despite the low activity levels, frequent sleep, and occasional feeding (Sergeant 1973, 1991) that characterize this time of the year. The declines in mass measured between the April 26 and May 10 periods were equivalent to $22 \mathrm{MJ} \mathrm{d}^{-1}(4.2 \times \mathrm{SMR})$ in the youngest males, more than $40 \mathrm{MJ} \mathrm{d}^{-1}$ (about $5 \times \mathrm{SMR}$ ) in males aged 4 to $8 \mathrm{yr}$, and $30 \mathrm{MJ} \mathrm{d}^{-1}(3.2 \times \mathrm{SMR})$ in old bulls. These high rates do not agree with the proposition that the molting period is one of relatively low energy expenditures in many phocids (Worthy 1990). Evidence for this is conflicting. SMR decreases for part of the molt in harbor seals (Ashwell-Erikson et al. 1986). In contrast, SMR increases during the molt of juvenile and, to some extent, adult grey seals (Boily 1996, Boily \& Lavigne 1997). Female northern elephant seals lose about $25 \%$ of their body mass during their $30 \mathrm{~d}$ of molting fast. This represents an ADMR of only $2 \times$ SMR. Slip et al. (1992) also reported a low ADMR of $1.73 \times$ SMR during the molt of southern elephant seals, and observed a mass loss of about $23 \%$ during the $36 \mathrm{~d}$ molting fast. However data from their Table 2 show that these males derived $290 \mathrm{MJ} \mathrm{d}^{-1}$ on average from body stores, which is $4 \times \mathrm{SMR}$ for mammals of this size (mean of $1487 \mathrm{~kg}$ ). Furthermore, these molting males were losing mass faster $\left(9.6 \mathrm{~kg} \mathrm{~d}^{-1}\right)$ than northern elephant seal bulls during the breeding season $\left(7.1 \mathrm{~kg} \mathrm{~d}^{-1}\right.$ : Deutsch et al.
1990). Clearly more work is needed before general conclusions on the energetics of molting phocids can be made. Even though our study included ample samples for many periods, it is clear that more data are needed in late March and early April, as well as May and early June, to better understand the molting cycle of harp seal bulls and to quantify the cost of breeding and molting. Furthermore, the pattern of pelage shedding and hair growth needs to be described in more detail, including not only whether or not hair is fast or loose, but also the extent (degree) of shedding.

\section{Summer period}

Most harp seals migrate to Arctic waters during the summer months (Sergeant 1965, Stenson \& Sjare 1997), where they are reported to feed (Finley et al. 1990, Sergeant 1991). Although no data from the summer period were included in this study, it does not appear that they become very fat, considering that most harp seals shot in high-latitude waters in summer sink (Sergeant 1991). Nevertheless, male harp seals do gain mass during the summer, for they return to the study area heavier, in better condition, and with a thicker blubber layer than when they left in May. Rates of mass gains were very low, however, possibly because harp seals accomplish 2 long migrations between May and November. In absolute terms, males of intermediate age ( 8 to $12 \mathrm{yr}$ ) gained the most mass. They must accumulate the energy reserves necessary for breeding the following winter, in addition to completing their growth. In proportion to their size, males from 4 to $7 \mathrm{yr}$ experienced the most important gains $\left(>40 \% \quad M_{\mathrm{t}}\right)$. In summer, harp seals replenish the energy stores in their core faster than those in their blubber.

We have shown that male harp seals from this population reach their maximum size and condition in February. Northeast Atlantic harp seals, on the other hand, attain peak values of $B$ and $M_{\mathrm{s}}$ (as estimated by the index of Ryg et al. 1990) while still on their high-latitude feeding grounds in September and October (Nilssen et al. 1997). The difference between the 2 populations could be related to migration distance, since NW Atlantic harp seals migrate over 25 to $30^{\circ}$ of latitude (3000 to $4000 \mathrm{~km}$ ) (Finley et al. 1990, Sergeant 1991), whereas NE Atlantic harp seals migrate over only $15^{\circ}$ of latitude (Nilssen et al. 1997). Such a large difference in migration distance may have an impact on harp seals in different ways. It is likely that NE Atlantic harp seals spend less time migrating and more time feeding on their summer grounds than their NW Atlantic counterparts. Seals from both populations can be seen in Arctic waters from mid-June to October 
(Finley et al. 1990, Nilssen et al. 1997), but little is known of the time spent feeding at high latitudes by individual seals. The migration itself could affect the condition of harp seals, depending on the cost of locomotion and on feeding opportunities during migration. NW Atlantic harp seals are known to feed during the southward migration, which lasts approximately from October to December (Sergeant 1991), but too little is known on the intensity of feeding and the cost of locomotion to estimate the energy balance of migrating harp seals. Recent evidence from satellite telemetry that some seals accomplish the migration both ways twice in the same year (Stenson \& Sjare 1997) suggests that locomotion is not very costly for these animals. New samples of migrating and summering individuals are needed to quantify the timing and amplitude of mass gains and changes in body composition in summer and fall.

Acknowledgements. We are very grateful to N. B. Cadigan for his help with the comparison of growth curves, and M. C. S. Kingsley for his helpful discussions on growth curves. We wish to thank D. Bowen and I. H. Ni for their efforts in obtaining samples for many years of the study, and D. M. Lavigne and M. O. Hammill for making available to us their morphometric data. We also thank M. O. Hammill, J. Lawson, R. Miller and 3 anonymous reviewers for their helpful comments on the manuscript. In particular we thank 1 of the reviewers for his suggestion regarding the sculp and core condition indices we used. We are especially grateful to W. Penny, D. Wakeham and D. McKinnon, who measured the majority of the seals. In addition, W. Penny determined the age of the seals and D. Wakeham compiled the dataset and updated it regularly.

\section{LITERATURED CITED}

American Society of Mammalogists (1967) Standard measurements of seals. J Mamm 48:459-462

Anderson SS, Fedak MA (1985) Grey seal males: energetic and behavioural links between size and sexual success. Anim Behav 33:829-838

Anderson SS, Harwood J (1985) Time budgets and topography: how energy reserves and terrain determine the breeding behaviour of grey seals. Anim Behav 33: $1343-1348$

Ashwell-Erikson S, Hay FH, Elsner R, Wartzok D (1986) Metabolic and hormonal correlates of molting and regeneration of pelage in Alaskan harbor and spotted seals (Phoca vitulina and Phoca largha). Can J Zool 64:1086-1094

Baker SR, Barrette C, Hammill MO (1995) Mass transfer during lactation of an ice-breeding pinniped, the grey seal (Halichoerus grypus), in Nova Scotia, Canada. J Zool (Lond) 236:531-542

Beck GG, Smith TG (1995) Distribution of blubber in the northwest Atlantic harp seal, Phoca groenlandica. Can J Zool 73:1991-1998

Beck GG, Smith TG, Hammill MO (1993) Evaluation of body condition in the Northwest Atlantic harp seal (Phoca groenlandica). Can J Fish Aquat Sci 50:1372-1381

Blix AS, Grav HJ, Ronald K (1979) Some aspects of tempera- ture regulation in newborn harp seal pups. Am J Physiol 236:R188-R197

Boily P (1995) Theoretical heat flux in water and habitat selection of phocid seals and beluga whales during the annual molt. J Theor Biol 172:235-244

Boily P (1996) Metabolic and hormonal changes during the molt of captive gray seals (Halichoerus grypus). Am J Physiol 270:R1051-1058

Boily P, Lavigne DM (1995) Resting metabolic rates and respiratory quotients of gray seals (Halichoerus grypus) in relation to time of day and duration of food deprivation. Physiol Zool 68:1181-1193

Boily P, Lavigne DM (1997) Developmental and seasonal changes in resting metabolic rates of captive female grey seals. Can J Zool 75:1781-1789

Bowen WD, Sargeant DE, Oritsland T (1983) Validation of age determination in the harp seal, Phoca groenlandica, using dentinal annuli. Can J Fish Aquat Sci 40:1430-1441

Brody S (1964) Bioenergetics and growth. Hafner Publ Co, Inc, New York

Chabot D, Stenson GB (2000) Implantation date, growth rate and allometric relationships in foetal Northwest Atlantic harp seals (Phoca groenlandica). Can J Zool 78:1-5

Chabot D, Stenson GB, Cadigan NB (1996) Short- and longterm fluctuations in the size and condition of harp seal (Phoca groenlandica) in the Northwest Atlantic. Northwest Atl Fish Organ Sci Coun Stud 26:15-32

Cleveland WS (1979) Robust locally weighted regression and smoothing scatterplots. J Am Stat Assoc 74:829-836

Costa DP, Le Boeuf BJ, Huntley AC, Ortiz CL (1986) The energetics of lactation in the northern elephant seal, Mirounga angustirostris. J Zool Lond 209:21-33

Deutsch CJ, Haley MP, Le Boeuf BJ (1990) Reproductive effort of male northern elephant seals: estimates from mass loss. Can J Zool 68:2580-2593

Fedak MA, Anderson SS (1982) The energetics of lactation: accurate measurements from a large wild mammal, the grey seal (Halichoerus grypus). J Zool Lond 198:473-479

Fedak MA, Anderson SS (1987) Estimating the energy requirements of seals from weight changes. In: Huntley AC, Costa DP, Worthy GAJ, Castellini MA (eds) Approaches to marine mammal energetics, Vol 1. Society for Marine Mammalogy Special Publication. Allen Press, Lawrence, KS, p 205-226

Feltz ET, Fay FH (1966) Thermal requirements in vitro of epidermal cells from seals. Cryobiology 3:261-264

Finley KJ, Bradstreet MSW, Miller GW (1990) Summer feeding ecology of harp seals (Phoca groenlandica) in relation to arctic cod (Boreogadus saida) in the Canadian High Arctic. Polar Biol 10:609-618

Fisher HD (1954) Studies on reproduction in the harp seal Phoca groenlandica Erxleben in the Northwest Atlantic. Fish Res Board Can Manuscr Rep Ser 588

Gales R, Renouf D, Noseworthy E (1994) Body composition of harp seals. Can J Zool 72:545-551

Hammill MO, Kingsley MCS, Beck GG, Smith TG (1995) Growth and condition in the Northwest Atlantic harp seal. Can J Fish Aquat Sci 52:478-488

Hedd A, Gales R, Renouf D (1997) Inter-annual consistency in the fluctuating energy requirements of captive harp seals Phoca groenlandica. Polar Biol 18:311-318

Hindell MA, Slip DJ, Burton HR (1994) Body mass loss of molting female southern elephant seals, Mirounga leonina, at Macquarie Island. Polar Biol 14:275-278

Innes S, Stewart REA, Lavigne DM (1981) Growth in Northwest Atlantic harp seals Phoca groenlandica. J Zool Lond 194:11-24 
Kingsley MCS, Nagy JA, Russell RH (1983) Patterns of weight gain and loss for grizzly bears in northern Canada. Int Conf Bear Res Manag 5:174-178

Kjellqwist SA, Haug T, Øritsland T (1995) Trends in age composition, growth and reproductive parameters of Barents Sea harp seals, Phoca groenlandica. ICES J Mar Sci 52: 197-208

Kleiber M (1975) The fire of life: an introduction to animal energetics. Robert E Krieger Publishing Co, New York

Kovacs KM, Lavigne DM (1985) Neonatal growth and organ allometry of Northwest Atlantic harp seals (Phoca groenlandica). Can J Zool 63:2793-2799

Kovacs KM, Lavigne DM, Innes S (1991) Mass transfer efficiency between harp seal (Phoca groenlandica) mothers and their pups during lactation. J Zool Lond 223: $213-221$

Lager AR, Nordøy ES, Blix AS (1994) Seasonal changes in food intake of harp seals (Phoca groenlandica) at $69^{\circ} \mathrm{N}$. Mar Mamm Sci 10:332-341

Laws RM (1959) Accelerated growth in seals with special reference to the Phocidae. Norsk Hvalfangst-Tid 9: 425-452

Lucas A (1993) Bioénergétique des animaux aquatiques. Masson, Paris

Lydersen C, Kovacs KM (1993) Diving behaviour of lactating harp seal, Phoca groenlandica, females from the Gulf of St. Lawrence, Canada. Anim Behav 46:1213-1221

Lydersen C, Kovacs KM (1996) Energetics of lactation in harp seals (Phoca groenlandica) from the Gulf of St. Lawrence, Canada. J Comp Physiol B Biochem Syst Environ Physiol 166:295-304

Markussen NH (1995) Changes in metabolic rate and body composition during starvation and semistarvation in harbour seals. In: Blix AS, Walløe L, Ulltang Ø (eds) Whales, seals, fish and man. Elsevier Science BV, Amsterdam, p 383-391

Markussen NH, Ryg M, Øritsland NA (1992) Metabolic rate and body composition of harbour seals, Phoca vitulina, during starvation and refeeding. Can J Zool 70: 220-224

McLaren IA (1993) Growth in pinnipeds. Biol Rev 68:1-79

Merdsoy BR, Curtsinger WR, Renouf D (1978) Preliminary underwater observations of the breeding behavior of the harp seal (Pagophilus groenlandicus). J Mamm 59: 181-185

Miller EH, Stewart ARJ, Stenson GB (1998) Bacular and testicular growth, allometry, and variation in the harp seal (Pagophilus groenlandicus). J Mamm 79:502-513

Myers RA, Bowen WD (1989) Estimating bias in aerial surveys of harp seal pup production. J Wildl Manag 53:361-372

Nazarenko YI (1975) Sexual maturation, reproductive rate, and missed pregnancy, in female harp seals. Rapp P-V Réun Cons Int Explor Mer 169:413-415

Nilssen KT (1995) Seasonal distribution, condition and feeding habits of Barents Sea harp seals (Phoca groenlandica). In: Blix AS, Walløe L, Ultang Ø (eds) Whales, seals, fish and man, Vol IV. Elsevier Science BV, Tromsø, p 241-254

Nilssen KT, Haug T, Grotnes PE, Potelov V (1997) Seasonal variation in body condition of adult Barents Sea harp seals (Phoca groenlandica). J Northwest Atl Fish Sci 22: $17-25$

Oftedal OT, Bowen WD, Widdowson EM, Boness DJ (1989) Effects of suckling and the postsuckling fast on weights of the body and internal organs of harp and hooded seal pups. Biol Neonat 56:283-300

Oftedal OT, Bowen WD, Boness DJ (1996) Lactation perfor- mance and nutrient deposition in pups of the harp seal, Phoca groenlandica, on ice floes off Southeast Labrador. Physiol Zool 69:635-657

Ouellette J, Ronald K (1985) Histology of reproduction in harp and grey seals during pregnancy, postparturition, and estrus. Can J Zool 63:1778-1796

Paine RT (1971) The measurement and application of the calorie to ecological problems. Annu Rev Ecol Syst 2: $145-164$

Peters RH (1983) The ecological implications of body size. In: Beck E, Birks HJB, Connor EF (eds) Cambridge studies in ecology. Cambridge University Press, Cambridge

Reilly JJ, Fedak MA (1991) Rates of water turnover and energy expenditure of free-living male common seals (Phoca vitulina). J Zool Lond 223:461-468

Renouf D, Gales R (1994) Seasonal variation in the metabolic rate of harp seals: unexpected energetic economy in the cold ocean. Can J Zool 72:1625-1632

Renouf D, Gales R, Noseworthy E (1993) Seasonal variation in energy intake and condition of harp seals: is there a harp seal morph? Problems for bioenergetic modelling. J Zool Lond 230:513-528

Rosen DAS, Renouf D (1995) Variation in the metabolic rates of captive harbour seals. In: Blix AS, Walløe L, Ultang Ø (eds) Whales, seals, fish and man. Elsevier Science BV, Amsterdam, p 393-399

Ryg M, Smith TG, Øritsland NA (1988) Thermal significance of the topographical distribution of blubber in ringed seals (Phoca hispida). Can J Fish Aquat Sci 45:985-992

Ryg M, Lydersen C, Markussen NH, Smith TG, Øritsland NA (1990) Estimating the blubber content of phocid seals. Can J Fish Aquat Sci 47:1223-1227

SAS Institute Inc. (1989) SAS/STAT ${ }^{\circledR}$ user's guide, Version 6. 4 th edn. SAS Institute Inc, Cary, NC

SAS Institute Inc. (2000) JMP ${ }^{\circledR}$ statistics and graphics guide, JMP version 4. SAS Institute Inc, Cary, NC

Schmidt-Nielsen K (1984) Scaling: why is animal size so important? Cambridge University Press, Cambridge

Sergeant DE (1965) Migrations of harp seals Pagophilus groenlandicus (Erxleben) in the Northwest Atlantic. J Fish Res Board Can 22:433-463

Sergeant DE (1973) Feeding, growth, and productivity of northwest Atlantic harp seals (Pagophilus groenlandicus). J Fish Res Board Can 30:17-29

Sergeant DE (1991) Harp seals, man and ice. Can Spec Publ Fish Aquat Sci 114

Shelton PA, Stenson GB, Sjare B, Warren WG (1996) Model estimates of harp seal numbers-at-age for the Northwest Atlantic. Northwest Atl Fish Organ Sci Coun Stud 26:1-14

Sivertsen E (1941) On the biology of the harp seal Phoca groenlandica Erxl. Investigations carried out in the White Sea 1925-1937. Hvalrådets Skr 26:1-166

Slip DJ, Gales NJ, Burton HR (1992) Body mass loss, utilisation of blubber and fat, and energetic requirements of male southern elephant seals, Mirounga leonina, during the moulting fast. Aust J Zool 40:235-243

Stenson GB, Sjare B (1997) Seasonal distribution of harp seals, Phoca groenlandica, in the Northwest Atlantic. Int Counc Explor Sea Comm Fleet 1997/CC:10

Stewart REA, Lavigne DM (1984) Energy transfer and female condition in nursing harp seals Phoca groenlandica. Holarct Ecol 7:182-194

Stewart REA, Murie DJ (1986) Food habits of lactating harp seals (Phoca groenlandica) in the Gulf of St Lawrence in March. J Mamm 67:186-188

Sullivan RM (1981) Aquatic displays and interactions in har- 
bor seals (Phoca vitulina), with comments on mating systems. J Mamm 62:825-831

Synergy Software (2000) KaleidaGraph, 5th edn. Synergy Software, Reading, PA

Thompson P (1988) Timing of mating in the common seal (Phoca vitulina). Mamm Rev 18:105-112

Thompson P, Rothery P (1987) Age and sex differences in the timing of moult in the common seal, Phoca vitulina. J Zool Lond 212:597-603

Tinker MT, Kovacs KM, Hammill MO (1995) The reproductive behavior and energetics of male gray seals (Halichoerus grypus) breeding on a land-fast substrate. Behav Ecol Sociobiol 36:159-170

Trites AW, Bigg MA (1996) Physical growth of northern fur seals (Callorhinus ursinus): seasonal fluctuations and migratory influences. J Zool Lond 238:459-482

Walker BG, Bowen WD (1993) Changes in body mass and feeding behaviour in male harbour seals, Phoca vitulina, in relation to female reproductive status. J Zool Lond 231:423-436

Editorial responsibility: Otto Kinne (Editor), Oldendorf/Luhe, Germany
Wood AJ, Cowan I McT, Nordan HC (1962) Periodicity of growth in ungulates as shown by deer of the genus Odocoileus. Can J Zool 40:593-603

Worthy GAJ (1990) Nutritional energetics in marine mammals: addendums. In: Dierauf LA (ed) CRC handbook of marine mammal medicine: health, disease, and rehabilitation. CRC Press, Boca Raton, FL, p 489-520

Worthy GAJ, Lavigne DM (1983a) Changes in energy stores during postnatal development of the harp seal, Phoca groenlandica. J Mammal 64:89-96

Worthy GAJ, Lavigne DM (1983b) Energetics of fasting and subsequent growth in weaned harp seal pups, Phoca groenlandica. Can J Zool 61:447-456

Worthy GAJ, Lavigne DM (1987) Mass loss, metabolic rate, and energy utilization by harp and gray seal pups during the postweaning fast. Physiol Zool 60:352-364

Worthy GAJ, Morris PA, Costa DP, Le Boeuf BJ (1992) Moult energetics of the northern elephant seal (Mirounga angustirostris). J Zool Lond 227:257-265

Submitted: April 17, 2000; Accepted: May 17, 2001

Proofs received from author(s): February 4, 2002 